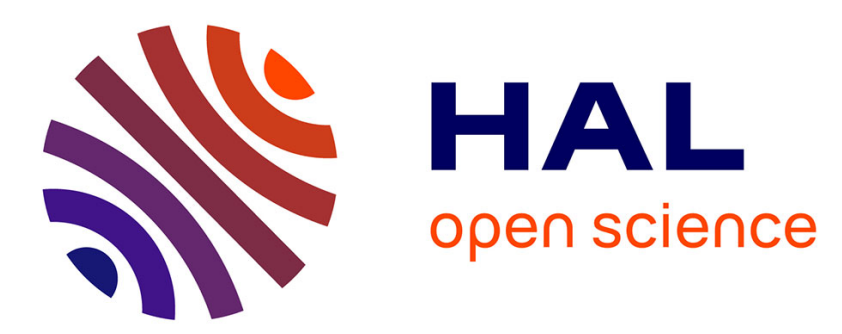

\title{
The success of Expert Recommending Services and the part played by organizational context
}

\author{
Claudio Vitari
}

\section{To cite this version:}

Claudio Vitari. The success of Expert Recommending Services and the part played by organizational context. Knowledge Management Research and Practice, 2011, 9, pp.151-171. 10.1057/kmrp.2011.6 . hal-00807544

\section{HAL Id: hal-00807544 https://hal.science/hal-00807544}

Submitted on 4 Apr 2013

HAL is a multi-disciplinary open access archive for the deposit and dissemination of scientific research documents, whether they are published or not. The documents may come from teaching and research institutions in France or abroad, or from public or private research centers.
L'archive ouverte pluridisciplinaire $\mathbf{H A L}$, est destinée au dépôt et à la diffusion de documents scientifiques de niveau recherche, publiés ou non, émanant des établissements d'enseignement et de recherche français ou étrangers, des laboratoires publics ou privés. 


\title{
The success of Expert Recommending Services and
}

\section{the part played by organizational context}

\author{
Claudio Vitari \\ Claudio.Vitari@grenoble-em.com
}

Grenoble Ecole de Management

\begin{abstract}
Knowledge Management (KM) practice proposes a series of services designed to reduce the difficulty of sourcing knowledge, i.e. getting the right knowledge to the right people at the right time. The phenomenon studied here is a specific type of KM service - the Expert Recommending Service (ERS) - which contributes to achieving the difficult objective of getting the right expert to the right people at the right time, and the article identifies the dimensions of ERS success in different organizational contexts and the organizational characteristics that influence ERS success.
\end{abstract}

Research contributions are therefore two-fold. On one hand, our results show that, among all the organizational characteristics, being aware of others, and specifically of others' knowledge domains, influences ERS success. On the other hand, our results suggest that ERS success can be significantly measured by employing the following dimensions: Quality, Use, Satisfaction, Individual Net Benefit and Organizational Net Benefit. We also propose a set of recommendations for practitioners to help improve the success of their ERS, taking into account the informal expert recommending processes, improving the accessibility of all personnel to knowledge about their colleagues and considering the organizational characteristics, and in particular awareness, before launching new ERS.

Keywords:

Information systems, knowledge management, success, knowledge sourcing, awareness, Expert Recommending Services 


\section{Introduction}

The phenomenon studied in this research is a specific type of Knowledge Management (KM) service called the Expert Recommending Service. A service has been defined as. ".... a change in the condition of a person or entity, brought about as the result of the activity of some other person or entity, with the approval of the first person or entity" (Chesbrough and Spohrer 2006). KM practice proposes a series of services to personnel designed to ease their ability to source knowledge, i.e. to get the right knowledge to the right people at the right time: widespread examples include document retrieval services (via document management systems), or training services (via learning management systems). Among the variety of knowledge sourcing services, we label those services that try to contribute to the difficult objective of getting the right expert to the right people at the right time as Expert Recommending Services (hereafter ERS) (Reichling, Veith et al. 2007), although alternative labels exist, such as Expertise Locator (Leavitt 2004; Becerra-Fernandez 2006).

When specialized knowledge is needed, being aware of which individuals could be sources of it - knowing what other members of the organization know - is a first step towards seeking out and contacting a specific individual (Schwartz 2007; Kraaijenbrink and Wijnhoven 2008). ERS facilitate knowledge sourcing and develop awareness about potential knowledge providers by increasing the seeker's awareness of the knowledge domains of other members of their organization, and particularly by identifying who is expert in terms of the knowledge required. In fact, ERS identify and display a small subset of hand-picked individuals, who (to a greater or lesser extent), are understood to have the specialized knowledge needed by a potential recipient (Yimam-Seid and Kobsa 2000). Following this first step, awareness of others' knowledge domains and a common organizational and work context between the knowledge seeker and the expert provide the knowledge redundancy necessary for the successful transfer and integration of specialized knowledge (Bosua and Scheepers 2007; Rosendaal 2009). Looking at the phenomenon under study - the ERS - through the lens given above, the expert seeker and the expert recommender can be seen as the two interacting "entities", the activity of the recommender (as approved by the seeker) is the service, and the transfer to the seeker of knowledge about proposed experts (the potential 
sources of the knowledge the seeker needs) is the change in condition produced by the service.

The two main objectives of this study are (1) to clarify the dimensions of success of the ERS in different organizational contexts and (2) to understand the organizational characteristics that influence that success. These are important for several reasons. First of all, ERS are an innovative way to support direct knowledge transfer between people (Schwartz 2007), but since the academic community has not yet studied specifically how to measure its success, our understanding of that success is still incomplete (Gray and Meister 2006). The research community has developed different theories and models about the success of both Information Systems (IS) (Davis, Bagozzi et al. 1989; DeLone and McLean 1992; Seddon 1997) and Knowledge Management Systems (KMS) (Bots and de Bruiin 2002; Lindsey 2002; Massey, Montoya-Weiss et al. 2002; Vitari, Moro et al. 2006; Wu and Wang 2006), but still lacks a specific model to assess ERS success. Limited understanding of ERS success slows down the development of awareness about potential knowledge providers, hindering knowledge transfer between people, which is gaining relevance as organizations increasingly recognize that their personnel represent one of their most important resources. However, several forces (globalization, high personnel turnover, the number and geographical distribution of employees to mention but a few) are making it progressively more difficult to source knowledge - to locate and access others' expertise - in a timely fashion (Gray and Meister 2006; Apostolou, Abecker et al. 2007; Bosua and Scheepers 2007; Rosendaal 2009).

Secondly, ERS represent an irreplaceable knowledge sourcing service, once it is accepted that different knowledge sources (such as documents or conversations) are not perfect substitutes for each other, and have different performance outcomes (Gray and Meister 2006). For instance, individual conversations between colleagues can provide situated knowledge exchange that is simply not available from documents in a repository (Apostolou, Abecker et al. 2007). Different knowledge needs require different knowledge sourcing services, and they can be expected to perform differently depending on their organizational contexts (Wang, Ashleigh et al. 2006; Apostolou, Abecker et al. 2007; Bosua and Scheepers 2007). As a consequence, studying KM services as monolithic solutions restrains the generalizability of study results, while segmenting KM services and studying 
each single knowledge sourcing service separately increases the relevance of the study (Gray and Meister 2006).

Thirdly, the impact of the organizational context on ERS success has never been studied before, which is a significant gap in the literature, given that KM services seem not to be equally valid in delivering different services into different organizational contexts (Bosua and Scheepers 2007). In fact, the suitability of different mechanisms for transferring and integrating knowledge (Kane, Argote et al. 2005; Foss 2007; Schwartz 2007; Easterby-Smith, Lyles et al. 2008; Wijk, Jansen et al. 2008) depends on the properties of that knowledge and on the organizational context wherein it is to be transferred or integrated (Wang, Ashleigh et al. 2006; Bosua and Scheepers 2007).

Fourthly and finally, our focus on the "service" delivered is deemed appropriate, as the knowledge seeker may only partially be able to formulate or express what knowledge they hope to gain from the expert, so the precise identification of the specific knowledge and of the expert required may depend on interaction between the expert seeker and the expert recommender (Allison, Cerri et al. 2005; Spohrer and Riecken 2006): such interaction is a typical service component (Chesbrough and Spohrer 2006). And looking at ERS as a service allows us to focus on customer activities and concerns, and on how the seeker, recommender and expert co-produce value (Alter 2008).

This article is organized as follows. Due to the lack of academic research in the ERS success and in the impact of the organizational context we first present an explorative conceptual model of the success of ERS and of the impact of organizational context on that success. We then describe our confirmatory research model and outline the research methods for the two models. The collected data are then analyzed and the results for the explorative and the confirmatory models presented. Finally, the evidence emerging from this empirical study is discussed to validate the research model, and conclusions are drawn.

\section{Explorative conceptual model}

Our explorative conceptual model is intended to outline: (1) the most suitable dimensions for assessing ERS success, and their relationships; and (2) the relationship between that success and the characteristics of the organizational context. 


\section{ERS Success for its customers}

The lack of academic research into ERS success has led us to base our research on the broader research issue of system success for KMS and for IS generally. While the issue has been widely debated in the research community (Rai, Lang et al. 2002; Briggs, De Vreede et al. 2003), system success in these two domains is conventionally considered to be the degree to which the stakeholders benefit from the system (DeLone and McLean 1992), Given the variety of possible stakeholders and the diversity of benefits involved, methods for measuring system success will differ, but, to be effective, must define the perspective from which the success is to be measured - i.e. which stakeholders the model must take into consideration (Briggs, De Vreede et al. 2003) - and the specific dimensions of success, which accounts for the multi-dimensional nature of the success that has to be measured (Briggs, De Vreede et al. 2003). Thus, Chief Knowledge Officers (CKOs) and system users, for example, may consider different dimensions when evaluating KMS success - the formers' could include Total Cost of Ownership and Return On Investment, while customers' dimensions might be Ease of Use and Quality of Results.

Given the service orientation of this study, we focus on the customer perspective, i.e. the point of view of the receiver/user of the ERS, to define ERS success in our research model (Alter 2008).The fact that the customer can choose from among the variety of available knowledge sourcing services to research the specialized knowledge they require makes the demand for ERS volitional (i.e. non-compulsory).This research also acknowledges that both human and computer-based processors can be deployed as part of KMS (Holsapple and Wu 2008). Previous research has shown that both formal (i.e. computer-based) and informal systems - where information is delivered via a specific department or organizational members themselves - can supply ERS (Lesser and Strock 2004), so, given our service 'lens' and customer perspective, we consider both computer-based and informal ERS. Thus, to be suitable to our research, the model of ERS success has to apply to: (1) volitional (noncompulsory) contexts; (2) computer-based, paper-based and informal systems, and (3) the services provided by system, and these conditions are therefore included in our study. We reviewed many different theories and models of IS success (Davis, Bagozzi et al. 1989; DeLone and McLean 1992; Seddon 1997) and of KMS success (Bots and de Bruiin 2002; 
Lindsey 2002; Massey, Montoya-Weiss et al. 2002; Vitari, Moro et al. 2006; Wu and Wang 2006) to try to find which was applicable under these conditions and which was the most appropriate to evaluating the success of ERS from the customers' perspective.

One the one hand, models specifically developed to measure KMS success were thought not well suited for this study, both because their lack of significant external validity reduces their potential applicability into contexts different to their original settings, and the fact that ERS differs considerably from the KMS services such models are designed to measure (Folkens and Spiliopoulou 2004; Kankanhalli and Tan 2004). On the other hand, the general models for measuring IS success developed by Davis (Davis, Bagozzi et al. 1989), DeLone and McLean (DeLone and McLean 1992), and Seddon (Seddon 1997) have been successfully applied to a large variety of IS (including even some KMS) and have been extended over time so as to counteract their various major limitations. Table 1 presents the original models and their extensions in the areas of our three conditions: the contexts of applicability (volitional or non volitional), the types of IS to which they can be applied (computer-based, paper-based, and informal systems), the inclusion of the services provided by the system among the dimensions of IS success.

\section{Insert Table 1 here}

Our analysis pointed towards the updated DeLone and McLean's IS Success Model (DeLone and McLean 2003) (see Figure 1) as the most suitable model, as it best satisfies these three constraints. We justify this choice for four main reasons. First of all, it is a general model of IS success that has already been widely and successfully applied to different kinds of IS and also to measure KMS success (Jennex and Olfman 2003; Qian and Bock 2005; Wu and Wang 2006). Secondly, the model is designed to cope with both volitional and compulsory contexts (Rai, Lang et al. 2002). Thirdly, it has been used to measure the success of computer-based, formal paper-based and informal systems (Jennex 2005; Bernroider 2008). Finally, service quality is included in the model as part of the measure of service success (DeLone and McLean 2003; Jennex 2005). We therefore adopted DeLone and McLean model's variables (Quality, Use/Intention to Use, Satisfaction, Net Benefits) and their hypotheses as the first half of our two-fold explorative model.

\section{Insert Figure 1 here}




\section{Organizational context characteristics and their influence on ERS}

\section{success}

The second half of our explorative model proposes the organizational context as the independent variable influencing the success of ERS. In assessing the suitability of ERS in specific organizational contexts (Gray and Meister 2006), it is important to clarify which organizational characteristics are antecedents of ERS success. We therefore reviewed the literature about the organizational context characteristics that could influence the KMS success (Maier 2002; Koeglreiter, Smith et al. 2006; Rosendaal 2009) and identified those that could also be antecedents of ERS success. They are homogenized and synthesized as follows:

- Size: the number of people in the organization;

- Composition: the proportion of knowledge held in common between organizational members;

- Geographical distribution: the spread of members' geographic locations;

- Lifetime: how long the actual organizational structure has existed;

- Fragmentation: the number and structure of the organization's main divisions;

- Mode of interaction: the communication means used in interactions between members;

- Degree of interconnection: the proportions of one-to-one, many-to-many and one-tomany interactions between personnel;

- Frequency of interaction: the number of interactions over time;

- Anonymity: the general degree of visibility of other members' identity;

- Cohesion: the level of positive community feeling among organizational members

These characteristics are included as independent variables in our explorative model (see Figure 2), as we hypothesize they will all influence ERS success in some way.

\section{Insert Figure 2 here}




\section{Confirmatory research model}

Our confirmatory model is designed to structure our explorative conceptual research model results according to the most recent academic research, and to corroborate the proposed hypotheses (1) on ERS success, and (2) on the influence of organizational context on ERS success.

\section{ERS success from the customers' point of view}

We made four adaptations to the updated (2003) version of Delone and McLean's IS success model to make it more consistent with our emerging results about ERS success. These adaptations concern: (1) the Net Benefits dimension, (2) the Quality dimension, (3) the Use/Intention to Use dimension and (4) the Feedback loops between Net Benefits and Use/Intention to Use, and between Net Benefits and Satisfaction.

\section{Net Benefits}

In their updated model, all net benefits are gathered in one single variable for the sake of parsimony, even though their subsequent research justified the inclusion of other impact levels beyond the two (individual impact and organizational impact) originally identified in 1992: work-group impact, inter-organizational impact, industry impact, consumer impact and societal impact (DeLone and McLean 2003). In general, the choice of where the impact should be measured depends on the system being evaluated and on its purposes. But given that the system we evaluated is used by single members within single organizations, two measurement dimensions of net benefits seem pertinent and are thus retained: the Individual Net Benefit and Organizational Net Benefit levels. The links between these two dimensions the causal relationship between Individual and Organizational Net Benefits - is clearly affirmed in the literature (DeLone and McLean 2003) and was widely confirmed in our interviews.

\section{Quality}

Although DeLone and McLean (2003) identified three major dimensions of IS quality separately - Information Quality, Service Quality and System Quality - our interviewees perceived them as largely overlapping. First of all, System Quality (which corresponds to the 
production/technical level (Shannon and Warren 1949; Mason 1978) and it is not visible to users) did not seem to matter directly or significantly to the customers in our study. Information Quality - which corresponds to the product/semantic level (Shannon and Warren 1949; Mason 1978) - appeared to our interviewees to merge with the quality of their interactions with the ERS, which mainly concerned the service dimension of Quality. We therefore combined these three components (Information Quality, System Quality and Service Quality) and synthesized our evaluation into one overall 'Quality of ERS' measure.

\section{Use/Intention to Use}

The double dimension Use/Intention to Use proposed by DeLone and McLean's model requires making a choice between its two components. Our preference has been towards the Use dimension, because of the elements of voluntary use of ERS, of postadoption evaluation and the lack of any specific troubling concerns about a simple 'Use' dimension emerging from analyzing the interviews. The consequence of choosing 'Use' instead of 'Intention to Use' is that the causality of the relationship between Use and Satisfaction is from the former to the latter.

\section{Feedback loops}

DeLone and McLean's model proposes two feedback loops - the first from Net Benefits to Use/Intention to Use and the second from Net Benefits to Satisfaction - which both refer to the reinforcing effects that occur between those dimensions over time. Since our study is not a longitudinal one, these feedback loops have not been explicitly taken into account.

Apart from these four, the other dimensions and hypotheses of DeLone and McLean's updated IS success model proved to fit the ERS context and the customer perspective well. As the remaining dimensions and hypotheses are largely justified in their original presentation of their model, we do not explicitly justify their hypotheses here, but only list them.

- H1: The Individual Net Benefit positively influences the Organizational Net Benefit.

- H2: The level of ERS Use positively influences the Individual Net Benefit.

- H3: The Satisfaction positively influences the Individual Net Benefit. 
- H4: The level of ERS Use positively influences the Satisfaction.

- H5: The Quality of the ERS positively influences the Satisfaction.

- H6: The Quality of the ERS positively influences the level of ERS Use.

\section{Organizational context characteristics and ERS success}

The empirical exploration of the influence of organizational context characteristics on ERS success highlighted that, for the ERS customers, being aware of the knowledge domains of the other members was more important than all the other characteristics we examined (size, composition, geographical distribution, lifetime, fragmentation, mode of interaction, degree of interconnection, frequency of interaction, anonymity, cohesion). While a fuller description of this influence and justification of the related hypotheses is given in the Results section, this emerging influence is introduced here to support the development of two new hypotheses on the influence of the characteristics of the organizational context on the ERS success.

The explorative data suggests that being aware of others' knowledge domains impacts both ERS quality and the frequency of its use. First, customers who were made more aware of others' knowledge domains seemed to appreciate the quality of ERS more, and in particular the quality of its response to their need for an expert. In terms of their use of computer-based ERS, customers were probably more comfortable in using keywords and other familiar system parameters for finding experts, as they knew (better than other members) the kind of knowledge domains that already existed and thus chose the most effective terms to describe the knowledge they needed. So they obtained the best answers and perceived the best service quality as high. In the same way, informal ERS customers who were more aware of their colleagues' knowledge domains were in a better position to ask the right colleagues and in the right way and thus achieve a high quality result. So we can label Awareness of Others the variable measuring the degree to which the members are aware of the knowledge domains of other members, and we can propose a first hypothesis linking the organizational context characteristics and ERS success:

- H7: Awareness of Others positively influences the Quality of the ERS.

Secondly, we found the most frequent users of ERS among those customers who were more aware of other people's knowledge domains, whereas those who did not know 
their colleagues well often reported perceiving a barrier to contacting unknown colleagues, even if ERS announced them as the 'right' experts. We concluded that being unaware of others limited customers' use of ERS, (and thus their ability to profit from gaining good answers). Thus:

- H8: Awareness of Others positively influences the level of ERS Use

The emerging literature in information and knowledge sharing contexts and IS success already supports the argument that influences such as individual characteristics, informal relationships and awareness of others (Pinsonneault and Heppel 1997-8; Hertzum and Pejtersen 2000; Markus 2001; Koeglreiter, Smith et al. 2006; Martin 2006; Wang, Ashleigh et al. 2006; Bosua and Scheepers 2007; Case 2007) are important independent variables. On the other hand, our speculations that ERS success develops awareness of the knowledge domains of other members in their organization have been clarified. Given that any effects of ERS success on awareness will take place over long periods, this feedback loop was not taken explicitly into consideration in the confirmatory model, as it was felt longitudinal study was thought more appropriate for its measurement. Our two emerging hypotheses - together with the variable Awareness of Others - are included in the confirmatory model on ERS success and on the influence of the organizational context on ERS success illustrated as Figure 3.

\section{Insert Figure 3 here}

\section{Research methods}

The lack of research within the IS and KM disciplines on the dimensions of ERS success, and on the specific effects of organizational context on ERS success, prompted the author to adopt a multi-method research approach (Azad and King 2008) that involved an evolutionary perspective. This study thus combines complementary qualitative and quantitative research methods, and employs the best-established methodologies (Palvia, Pinjani et al. 2007) to provide a richer contextual basis for interpreting and validating its results (Younbok and Ho-Jin 2005). The explorative qualitative multiple case study was carried out before the confirmatory quantitative opinion research was undertaken. Mutschler, Reichert et al (2008) have previously integrated case study and opinion research in this way, and shown that these complementary research methods can help triangulate results properly. 


\section{Explorative qualitative method}

The qualitative method is used to explore the dimensions of ERS success, the characteristics of the organizational context and the relationships between the two. This exploration is aimed at generating a model of ERS success from the customers' perspective, with the organizational context characteristics included as external variables. The case study research method was chosen as the most suitable qualitative methodology as our object was to generate a model to describe a contemporary phenomenon. Case study research has a strong potential for theory generation (Myers 2004), and is extremely applicable to the study of contemporary phenomena within real-life contexts, especially when the boundaries between phenomenon and context are not clearly evident (Yin 2002). Moreover, a multiple case design has been applied, following theoretical sampling, with the case sample being sized on theoretical saturation (Yin 2002). Five heterogeneous case organizations were selected (identified hereafter as NSS, MM, FST, BESR and ESCC) which displayed contrasting characteristics useful for our theoretical sampling: organization type, main activity sector, global revenue, employee numbers, global geographical distribution, organizational section examined and existing computer-based ERS (see Table 2).

\section{Insert Table 2 here}

The cases were analyzed using data collected from primary (interviews, direct observations and informal discussions) and secondary (mainly the output documents of the organizational IS) sources. An internal referee in each organization assisted us in identifying and contacting potential interviewees for our semi-structured interviews, where we aimed at gaining the maximum level of heterogeneity (particularly in terms of job position) so as to explore the convergence of information from such different sources (Yin 2002). Officers of both the ERS facility and the wider organization were also interviewed to improve the heterogeneity of the sample. An interview guide was drafted listing the main themes: the interviewee's role in their organization, the organizational context characteristics, and the interviewee's perspective as to the success, benefits and limitations of ERS in their organization. Each interview began with an introduction about the rationale and objects of the study, to help reduce the chance of researcher effects biasing data collection. 
The qualitative data thus produced were all recorded and fully transcribed, and the transcripts, our direct observation field notes and the secondary data we collected were archived in a repository. Each transcript was then analyzed and cross-matched with accounts of other interviews, so the content of one could be used as a source of questions for the next. In analyzing and interpreting interview data, the author chose the thematic content analysis method (Krippendorff 2004) to understand the transcripts, which involves defining a set of analysis themes and sub-themes, and then matching transcript sentences to one or more of them. The premise of content analysis is that the spoken repetition of a chosen unit of analysis (words, phrases, sentences or paragraphs) highlights both the speakers' centers of interest and their opinions. The author defined the analysis units as sentences, parts of sentences or groups of sentences, which were then grouped together based on their relation to organizational context and ERS success. During the course of the interviews, the list of themes and sub-themes was refined and modified to include emerging elements, and when the analysis revealed saturation and repetition of identical themes, no further interviews were scheduled: altogether, 35 interviews were conducted.

The codification system followed a descriptive approach, with second level codes further specifying first level codes. The first level codes followed the two main themes organizational context characteristics and ERS success - with organizational context characteristics (Size, Composition, Geographical distribution, Lifetime, Fragmentation, Mode of interaction, Degree of interconnection, Frequency of interaction, Anonymity, Cohesion) as the second level organizational context codes, and the five IS success dimensions (Quality, Use, Satisfaction, Individual Net Benefit, Organizational Net Benefit) as the second level ERS success codes. A computer-aided qualitative data analysis system was required to support codification and analysis, and after some personal tests and considering the review by Lewins (Lewins and Christina 2005), ResearchWare@ HyperRESEARCH ${ }^{\mathrm{TM}}$ was chosen for this purpose due to its user-friendliness and its flexibility in report building.

\section{Confirmatory quantitative method}

The quantitative method was used to confirm statistically the main results emerging from the explorative case study concerning the dimensions of ERS success and the influential organizational context characteristics, aiming to validate the confirmatory ERS success 
model, including the organizational context characteristic Awareness of Others as the external variable. This objective made opinion research the most suitable quantitative research method (Straub, Gefen et al. 2006), due to its strong potential for testing hypotheses. A questionnaire-based survey was the main source of empirical data. The model constructs were all operationalized using scales measuring customers' perceptions (as found in the existing literature) hence avoiding the need for a pilot study (See Table 3 for all the items included in each construct).

\section{Insert Table 3 here}

\section{Awareness of Others}

During the case study, Awareness of Others emerged as the key organizational context characteristic impacting the success of the ERS, and was therefore operationalized as an external variable influencing IS success. Pinsonneault and Heppel's Awareness of Others construct is a component of their Anonymity concept (Pinsonneault and Heppel 19978) and is based on social psychology (Mathes and Guest 1976; Johnson and Downing 1979; Propst 1979; Nadler, Goldbert et al. 1982; Solomon, Solomon et al. 1982). This construct was adapted for this study to measure the degree to which people are aware of others' knowledge domains.

\section{Quality}

The Quality construct measures the customer's global judgment about the superiority of the ERS (Parasuraman, Zeithaml et al. 1988) as a service, rather than as a product. From the point of view of the ERS customers, quality implicitly includes information quality, system quality and service quality. The scale used to measure Quality in this study is an adapted version of an existing service quality scale (Spreng and Mackoy 1996) - originally developed in Marketing discipline (Parasuraman, Zeithaml et al. 1988) - to make it consistent with the specificities of ERS.

\section{Use}

Use measures the frequency of customers' utilization of ERS, which means the frequency of their demands for expert recommendation. Use could be measured through subjective measures (Lucas 1975; Lucas 1978; Maish 1979; Fuerst and Cheney 1982; Raymond 1985; DeLone 1988) or by objective measures (Swanson 1974; King and 
Rodriguez 1978; Lucas 1978; King and Rodriguez 1981). The inclusion of informal ERS favored subjective measures of use, due to the intrinsic difficulties in collecting objective measures on informal ERS. In the end, we used a construct composed of a two item semantic scale, merging two different single item scales from Yoon and Guimaraes (1995) and Bajaj and Nidumolu (1998).

\section{Satisfaction}

Satisfaction "in a given situation, is the sum of the one's feelings or attitudes toward a variety of factors affecting that situation" (Bailey and Pearson 1983 page 531). Zviran and Erlich (2003) reviewed the use of the Satisfaction construct in the IS discipline and reported that it involved different aspects. Transposed to the ERS context, the aspects of satisfaction considered concerned the customer's emotional state following the provision of the ERS and in line with Bhattacerjee and Premkumar's proposal - involved two dimensions: valence (positive vs. negative) and intensity (Bhattacherjee and Premkumar 2004). Hence, again, the Satisfaction measure involves adapting their existing scale to the study context to assess the customer's emotional feelings towards ERS provision.

\section{Individual Net Benefit}

In our study, customers perceived the direct impact ERS on their performance (Goodhue and Thompson 1995) as the major individual net benefit from their point of view, so Goodhue and Thompson's (1995) the Individual Performance Impact variable was used to measure Individual Net Benefit. Their original scale was adapted to relate specifically to customer's perceptions of the improvement of their performance that resulted from their use of ERS.

\section{Organizational Net Benefit}

Among the various possible types of organizational net benefits (Mirani and Lederer 1998), our empirical exploration reveals that ERS customers identify the most significant as the improvement in their access to information about experts: greater access to such information was seen as the first step to gaining knowledge from them. Hence, the Information Access variable (Mirani and Lederer 1998) was used to measure Organizational Net Benefit, and the Mirani and Lederer (1998) scale was adapted to the ERS context to measure the specific contribution of ERS in improving such access. 
Questions were randomly distributed throughout the questionnaire to reduce common methods bias (Straub, Boudreau et al. 2004), and each construct was measured by more than one item to avoid mono-operation bias. Colleagues and potential respondents reviewed the questionnaire to help refine it and improve its fit with the organizational context, and the final version was published on a web server accessible to all members of the three organizations that agreed to participate: NSS, MM and FST. These members were invited to fill in the questionnaire by e-mails sent by the internal referents, and when the weekly response rate decreased to zero, a recall was e-mailed to all members. Although the questionnaire was sent out via email, the answers were collected via a web form, so that response data could be automatically stored in a database. A preliminary data quality analysis was performed. Structural Equation Modeling (SEM) statistical techniques was used as the principal statistical method for quantitative analysis, a procedure that is recommended as an advanced method for validating this kind of model because of the potential sophistication of its results (Boudreau, Gefen et al. 2001), and because its assumption was compatible with the data. The data analysis followed Straub, Boudreau and Gefen's (2004) validation guidelines, which seek to ensure content validity, construct validity, reliability, manipulation validity and statistical conclusion validity. Statistical data analysis was supported by packaged software: SPSS $\odot$ and Amos $\odot$ were chosen after several packages had been reviewed, directly and indirectly (Gefen, Straub et al. 2000; Straub, Gefen et al. 2006).

\section{Results}

In describing main results of our proposed explorative model and the confirmatory models test, we focus on: (1) the characteristics of the organizational context, (2) the relationship between organizational context characteristics and ERS success, and (3) the corroboration of the confirmatory model's hypotheses.

\section{Characteristics of the organizational context}

The five studied organizations are heterogeneous in most of their organizational context characteristics, as Table 4 shows. The main common factor is that members have the opportunity to develop informal links freely with members of other organizational groups. As part of their normal working activities, people tend naturally to develop - gradually and 
spontaneously - new links that circumvent or complement their formal structures. But our findings showed that such spontaneous links do not always develop successfully, and indeed are not always supported by management. The directors and deans at MM promote the creation of such informal links through several public initiatives and communications, but with only limited success. In contrast, NSS and BESR, aiming to become more efficient and effective organizations, have succeeded in creating informal links that overlap their organizational structures and strengthen relationships between colleagues by facilitating information sharing and knowledge transfer through meetings and presentations. As at NSS, such informal relationships develop around the employees' professional activities at FST, but the organization does not incentivize their creation, considering them a potential risk to organizational effectiveness, were personal conflicts to endanger an otherwise smooth business process. While informal relationships develop naturally at FST, they do not usually extend across different sites.

\section{Insert Table 4 here}

\section{The relationships between organizational context characteristics and ERS success}

ERS success in the studied organizations seemed to be influenced by informal relationships based on social and friendship ties between members, and this influence also emerged as significant in other knowledge sharing contexts (Wang, Ashleigh et al. 2006; Bosua and Scheepers 2007). As noted above, a grounded relationship between organizational context and ERS has been identified in the Awareness of Others construct, a component of the Pinsonneault and Heppel's (1997-8) Anonymity variable. In the ERS context, Awareness of Others specifically measures the degree of organizational members' awareness of each others' knowledge domains, and our findings indicate it was the organizational context characteristic that most influenced ERS success, across all our studied organizations. Several interviewees noted this clearly and explicitly.

"Asking colleagues for experts or information depends on their being an informal organization ....an informal network of knowledge about others" 
Although the relationship between Awareness of Others and system success has been established previously (Pinsonneault and Heppel 1997-8), the relationship between it and ERS success is not yet consolidated. But Case (2007) and Hertzum and Pejtersen (2000), for example, suggest that people searching for knowledge commonly explore their personal contacts before using formal sources, a view supported by our empirical evidence:

"I know all my colleagues in charge of the other businesses... so I can ask them to find the experts I am looking for among their subordinates...The team's spirit, between us, is strong, so as soon as I need an expert I ask my colleagues."

Or again:

"I know my colleagues here, so I ask them for expert recommendation. But I do not know my colleagues in the other sites, so I do not ask them for help."

Such uses members make of their personal contacts are determined by the level to which they have a social ties with each other, and are aware of each other's developed knowledge domains (Koeglreiter, Smith et al. 2006; Martin 2006; Wang, Ashleigh et al. 2006; Bosua and Scheepers 2007):

"I ask colleagues who I know well, I am confident with them ...I know that I can get [the information I need] from them easily."

This point of view was largely shared across the different organizations, and respondents were generally conscious of the potential barriers involved in consulting someone unknown to them:

"I think affinity, knowledge and familiarity are the points that influence my search for experts. It's easier for me to ask someone I know than to ask a PhD student I don't know."

Markus (Markus 2001) suggests that enquirers' individual characteristics - of which we suggest Awareness of Others is one - will influence their selection of experts: "The ERS [depends on] individuals having knowledge of each other" and "If we do not know the people, the ERS does not work". On the other hand, individuals who are unaware of others tend to be constrained in their use of ERS, and express dissatisfaction with it: "I feel uncomfortable asking anyone I do not personally know" and again: "These tools help us, but, at the end, the difference is made by the relationship and credibility you build up day by day with your colleagues." 
This link between Awareness of Others and ERS was observed repeatedly and in a similar pattern across the five cases. In each organization, some members declared themselves to be aware of their colleagues' knowledge domains, while others seem largely unaware: those who appeared more aware were also those who used ERS more and evaluated the service positively. The particular aspects of ERS success that seemed to be directly affected by the Awareness of Others were the decision to use it, and the appreciation of its quality. Compared to this factor, other organizational context characteristics seemed to have far less impact on ERS success, a finding that was again consistent across the five cases. It was therefore inferred that the relationship between organizational context's characteristics and ERS success could effectively be described by this one single synthetic measure: that was the inference that was tested and corroborated by the confirmatory model.

\section{The corroboration of the confirmatory model's hypotheses}

278 responses to the questionnaire were collected from 864 original invitations, of which 13 were eliminated as being incomplete, leaving 265 available for quantitative analysis (44 from MM, 51 from FST and 170 from NSS), giving an overall response rate of $31 \%$. The content validity, construct validity, reliability, and statistical conclusion validity tests proposed by Straub, Broudreau and Gefen (2004) for validating IS positivist research were applied to this empirical study.

\section{Content validity}

The literature was reviewed and experts, colleagues and ERS customers were consulted to assess the questionnaire's content validity, leading to refinements in terms of the kind and the number of questions. In particular, Awareness of Others was judged to have redundant items, and was reduced from 7 to 4 items.

\section{Construct validity}

The discriminant validity, the convergent validity, the factorial validity and the nomological validity were tested to assess the instrument's construct validity (a synthesis of the statistical results is available in Table 5). Confirmatory Factor Analysis (CFA) was run in SPSS to validate discriminant validity, before running CFA in AMOS showed the Quality and Satisfaction constructs as loading on the same factor. A second order CFA on these constructs highlighted an unexpected loading on the second factor of an item in the Quality 
instrument, which caused the discriminant validity test to fail. An examination of the reliability and convergent validity of the Quality construct highlighted the inadequacy of this item, which was traced back to a misunderstanding caused by the negative formulation of the statement that had not emerged during content validity. The scale's Cronbach's Alpha was unacceptable, but improved (to 0.715 ) when the item was deleted. Using AMOS allowed us to confirm the discriminant validity, by comparing the model's $x 2$ with that of an alternative model where the constructs in question were united as a single construct. The CFA technique in covariance-based SEM was employed to test convergent validity, and the results were all above the heuristics reported as acceptable by Gefen, Straub et al (2000). The same technique was employed to test factorial validity, resulting in fit statistics that again exceeded their recommended thresholds. In terms of nomological validity, all constructs in the model were based on those already used in the IS literature and adopted by several previous studies (Bhattacherjee and Premkumar 2004; Juhani 2005; Sabherwal, Jeyaraj et al. 2006; Agourram and Ingham 2007; Petter, DeLone et al. 2008). The proposed hypotheses had also all previously been tested in IS research, and even the emerging relationship between Awareness of Others and system success had been partially tested, as a dimension of the Anonymity construct tested in the context of IS success (Pinsonneault and Heppel 1997-8). The similarity of statistical significance among studies using the same validated instruments was another indication of nomological validity. In testing the structural model, all hypotheses were found to be significant, except $\mathrm{H} 4$, which posited the influence of Use on Satisfaction. While the relationship between these constructs has been discussed extensively in the literature (DeLone and McLean 1992; DeLone and McLean 2003; Garrity, Glassberg et al. 2005), empirical tests have yielded differing results. This hypothesis was not significant in our tests, but could be considered as being in line with some theoretical research streams (Seddon 1997).

\section{Insert Table 5 here}

\section{Reliability}

Internal consistency, split half and unidimensional reliability techniques were used to assess reliability (a synthesis of the statistical results is available in Table 6). Cronbach's $\alpha$ and Nunnally's rule of thumb was the technique/heuristic couple used to assess internal 
consistency, and all resultant Cronbach's a were above the recommended thresholds. SPSS was used to test the correlation between the halves of each construct: again, all the resulting values were above the cut-off points and all Cronbach's $\alpha$ were above the relevant thresholds. Covariance-based SEM was used to test unidimensional reliability, and examination of the actual modification indices revealed some cases as being above the thresholds. However their associated Reduced Parameter Changes gave us confidence in their unidimensionality, which was further confirmed when their standardized residual covariances showed no high residual values.

\section{Insert Table 6 here}

\section{Statistical conclusion validity}

The covariance-based SEM technique was applied via the Amos application, and the run of the model in Amos showed its overall fitness was good, with all indices above their respective thresholds (Table 7). As the Modification Indexes were not large enough to suggest ad hoc modification of the model (Byrne 2001), post-hoc analysis appeared superfluous and was therefore not undertaken. As regards the individual hypotheses, all eight were statistically significant, except the $\mathrm{H} 4$ causal relationship of Use on Satisfaction, which was therefore not validated (see Figure 4).

\section{Insert Table 7 here}

\section{Insert Figure 4 here}

\section{Discussion}

These results prompt discussion about the success of ERS and the effects of organizational context on that success, which, in turn, contributes to the broader exploration of knowledge sourcing services. The repetition of the same questions in the interviews in this multiple-case study and our formal data collection methods contributed to substantiating the validity, reliability and generalizability of our findings. At the same time, the fact that the study conformed to the guidelines for validating positivist research suggests our SEM findings are also generalizable. 


\section{ERS Success for customers}

Our results represent our academic contribution in response to the lack of models specifically designed to measure the success of ERS for its customers, and the influence of organizational context characteristics on ERS success. In terms of the former, DeLone and McLean's IS success model proved sufficiently adaptable and valid to allow us to use it to measure the success of ERS from the users' point of view. While customers indicated different levels of approval for informal and computer-based ERS, they reported using both of them, sometimes as alternatives, sometimes as complements, confirming the correctness of our approach, which allows ERS success to be evaluated irrespective of its method of implementation, or of whether the provider is a colleague or the organization's formal computer-based system. Our results bear out our choice of a synthetic variable measuring quality, implicitly gathering together information, system and service qualities. The statistically significant hypotheses of our confirmation model involving ERS Quality substantiate the pertinence of retaining a service orientation for measuring such solutions (Allison, Cerri et al., 2005). Our analysis also validates the choice of the individual and organizational levels at which to measure the net benefits of ERS, since the hypotheses are statistically confirmed with high regression weights, meaning that if the ERS is beneficial for its customer, it also benefits their organization.

The critical variable of the model for ERS success has been Use. The relatively weak regression weights of the relationships between Quality and Use, and between Use and Satisfaction and the absence of statistical significance between Use and Satisfaction suggest we may have to think again about the role of the Use variable in the ERS success model, and success models in general. The issue concerning the inclusion of Use in the success model has never been closed in the academic community: other researchers have discovered (specifically concerning knowledge sourcing services) a lack in statistical significance between Use and the other dimensions of success (Liu, Olfman et al. 2005), while, in terms of IS success in general, suggestion have been made to exclude Use from the dimensions of IS success (Seddon 1997) and to reverse the relationship between Use and Satisfaction (Gelderman 1995; Guimaraes and Igbaria 1997). Our empirical data did not allow us to 
contribute further on this thorny issue - so fresh research on the role of Use in success models would be welcome.

\section{Influence of 'Awareness of Others' on ERS success}

In terms of the influence of organizational context characteristics on ERS success, Awareness of Others appears to be the predominant characteristic. Different levels of this factor influenced how ERS was requested and provided, and definitely impacted its success. Among the ERS success dimensions, being aware of others' knowledge domains influenced two components of ERS success: its perceived quality and the extent of its use: lack of awareness about others' knowledge domains, in the end, limited ERS success.

In terms of informal ERS, the study shows that the organizational members a knowledge seeker asks first are those whose knowledge domains they are aware of. The main providers of informal ERS are people with whom the seeker shares an office, or with whom they have an established social relationship (Wang, Ashleigh et al. 2006; Bosua and Scheepers 2007). This finding highlights the presence of a barrier against the provision of the ERS - and more generally - in terms of members asking for help from people they do not know. This barrier may even limit the success of a computer-based ERS which, in proposing a list of experts, does not take into account of whether the seeker knows them. These results show the importance of social components, acting as complements to technical factors, to the success of ERS. Of course, the author does not argue that the success of ERS is exclusively determined by Awareness of the Others - our literature review identified 10 organizational contexts characteristics that could influence ERS success. While these other factors also impact ERS success, they were excluded from our confirmatory study so as to retain its main focus on the Awareness of Others factor. Further research, which studies a wider range of such factors, may allow us a more complete understanding of ERS success and its antecedents.

\section{Influence of the ERS success on awareness: a virtuous cycle}

Our theoretical speculations have proposed that the ERS facilitates knowledge 
sourcing by developing the seeker's awareness of the knowledge domains of other members of their organization (Bosua and Scheepers 2007; Rosendaal 2009). Thus limited ERS success, by slowing down the development of awareness about potential knowledge providers, would hinder knowledge transfer and integration. We would argue that this process of the development of seekers' awareness would take place were ERS continued over a period of time, but measuring it would require a longitudinal study. In this study, the actual current awareness of the knowledge domains of other organizational members was identified as the most important independent variable influencing ERS success. Given the results of our exploratory and confirmatory models, we can affirm that, where there is at least some level of awareness of others, ERS will be used more frequently, and customers will appreciate its quality more: thus - over time - both awareness of others, and transfer and integration of knowledge, will rise. If the right starting conditions are in place, this can help promote a virtuous circle that will increase the success of ERS in the long term.

\section{Computer-based ERS: implications for practitioners}

ERS is a complement to other KMS services (Wu and Wang 2006; Nevo and Chan 2007) which do not directly facilitate the finding of experts as sources of specialized knowledge. ERS functionality should be considered as a complement to other knowledge sourcing services within an organization's KMS, rather than a functionally equivalent substitute. These observations and the scientific literature can help define some useful guidelines for the success of computer-based ERS. Replicating the well-understood individual process of informal expert recommending would increase the success of computer-based ERS, as it does for product recommendations (Aksoy, Bloom et al. 2006). Access to computer-based ERS is restricted in some organizations, and could fruitfully be extended to all its members - such "openness" would increase its use, showing all employees the importance and usefulness of the data such systems hold about other individual members' knowledge in various domains. Our study of the impact of the organizational context offers further levers for the success of computer-based ERS. Given the emergence of the Awareness of Others variable as the organizational context aspect that most influences ERS success, our results affirm the importance of social factors and suggest that organizations 
conduct extensive analyses of these aspects, focusing on their members' awareness of others knowledge domains, before developing a computer-based ERS service.

The influence of organizational context on ERS success should also stimulate organizations to find ways to develop at least a minimum level of awareness about their members' knowledge domains, and actively seek to increase this factor, so as to facilitate knowledge sourcing via ERS. Such initiatives may differ across organizations: for example, FST regularly circulates information about newcomers and their knowledge domains to all employees, while other case organizations facilitate meetings and the internal mobility of employees. This factor is also interwoven with (and can be indirectly increased by) modifications to other organizational context characteristics. Changes in organizational structures or office locations can impact on opportunities for informal meetings, and increase members' awareness of their colleagues and their knowledge domains. Reputation systems (such as those used in online communities and marketplaces (Pavlou and Dimoka 2006)) could be used to develop an organization's sense of social cohesion and identification (Rosendaal 2009), helping to promote informal contacts. However, while there are many actions that might be taken to improve Awareness of Others among its members, an organization must take care not to disrupt those informal relationships and ERS structures that already exist.

\section{Conclusions}

Our study contributes (1) to clarifying the dimensions of success of the ERS in different organizational contexts and (2) to understanding the organizational characteristics that influence ERS success. Central to our investigation has been the assessment of ERS success. First, among the different models of success available in the literature we identified the most suitable for the ERS. Starting from DeLone and McLean's IS success model, we have identified the dimensions of ERS success from the customer perspective and statistically tested the causal relationships between the success dimensions. We confirm that DeLone and McLean's model of IS success is also valid for measuring ERS success, and discuss the role of Use among the dimensions of success. We therefore contribute to the academic effort to understand the success of knowledge sourcing services. At the same time, 
we suggest this clearer understanding of the dimensions of ERS success can help practitioners increase the success of their ERS, and thus improve their knowledge transfer capabilities. This study on a specific type of knowledge sourcing service - enriches research, complementing publications about other knowledge sourcing and management services, showing how they produce different outcomes and satisfy different objectives, and thus need to be analyzed specifically and separately. In this way, we offer practitioners specific levers to enhance their ERS, making it a more valid complement to the other knowledge sourcing services in their organizations.

The second key contribution of this study has been the exploration and confirmation of the effects of organizational context on ERS success, which has not previously been undertaken. We thereby fill a significant gap in the academic literature, given that KM services seem not to be equally valid in delivering different services into different organizational contexts, and given the potential effect organizational contexts can have on success (Bosua and Scheepers 2007). Seddon has already highlighted how observations, personal experiences and reports about the consequences of IS use impact its success (Seddon 1997). Our qualitative and quantitative data show that being aware of other people, and specifically of their knowledge domains, is a crucial element in ERS success, and confirms the link between Awareness of the Others and system success measured by Pinsonneault and Heppel (1997-8). As a practical consequence, organizations wishing to improve the success of their ERS should consider their organizational context, and try to ensure that conditions exist that can increase opportunities for informal encounters between its members, so as to help the development of a virtuous circle linking expert recommending with knowledge awareness and sourcing. 


\section{References}

Agourram, H. and J. Ingham (2007). "The impact of national culture on the meaning of information system success at the user level." Journal of Enterprise Information Management 20(6): 641 - 656.

Aksoy, L., P. N. Bloom, et al. (2006). "Should Recommendation Agents Think Like People?" Journal of Service Research 8(4): 297-315.

Allison, C., S. A. Cerri, et al. (2005). "Services, Semantics and Standards: Elements of a Learning Grid Infrastructure." Applied Artificial Intelligence Journal 19(9-10): 861879.

Alter, S. (2008). Moving Toward a Service Metaphor for Describing, Evaluating, and Designing Systems. European Conference for Information Systems. Galway, Ireland.

Apostolou, D., A. Abecker, et al. (2007). "Harmonising codification and socialisation in knowledge management." Knowledge Management Research \& Practice 5(4): 271.

Azad, B. and N. King (2008). "Enacting computer workaround practices within a medication dispensing system." European Journal of Information Systems 17: 264-278.

Bailey, J. E. and S. W. Pearson (1983). "Development Of A Tool For Measuring And Analyzing Computer User Satisfaction." Management Science 29(5): 530-545.

Bajaj, A. and S. R. Nidumolu (1998). "A feedback model to understand information system usage." Information \& management 33: 213-224.

Becerra-Fernandez, I. (2006). "Searching for Experts on the Web: A Review of Contemporary Expertise Locator Systems." ACM Transactions on Internet Technology 6(4): 333355.

Bernroider, E. W. N. (2008). "IT governance for enterprise resource planning supported by the DeLone-McLean model of information systems success." Information \& Management 45(5): 257-269.

Bhattacherjee, A. and G. Premkumar (2004). "Understanding changes in belief and attitude toward information technology usage: a theoretical model and longitudinal test." $\underline{\text { MIS }}$ Quarterly 28(2): 229-254.

Bosua, R. and R. Scheepers (2007). "Towards a model to explain knowledge sharing in complex organizational environments." Knowledge Management Research \& Practice 5(2): 93.

Bots, P. W. G. and H. de Bruiin (2002). Effective Knowledge Management in Professional Organizations: Going by the rules. Hawaii International Conference on System Sciences, IEEE Computer Society Press.

Boudreau, M.-C., D. Gefen, et al. (2001). "Validation in Information Systems Research: A State-of-the-Art Assessment." Management Information System Quarterly 25(1): 116.

Briggs, R. O., G.-J. De Vreede, et al. (2003). "Special Issue: Information Systems Success." Journal of Management Information Systems 19(4): 5-8.

Byrne, B. M. (2001). Structural Equation Modeling with AMOS. Mahwah, New Jersey, USA, Lawrence Erlbaum Associates.

Case, D. O. (2007). Looking for information: a survey of research on information seeking, needs, and behavior, Emerald Group Publishing.

Chesbrough, H. and J. Spohrer (2006). "A research manifesto for services science." Communications of the ACM 49(7): 35-40.

Davis, F., R. P. Bagozzi, et al. (1989). "User Acceptance of Computer Technology: A Comparison of Two Theoretical Models." Management science 35(8): 982-1003.

DeLone, W. H. (1988). "Determinants of Success for Computer Usage in Small Business." MIS Quarterly: 51-61.

DeLone, W. H. and E. R. McLean (1992). "Information systems success: the quest for the dependant variable." Information Systems Research 3(1): 60-95. 
DeLone, W. H. and E. R. McLean (2003). "The DeLone and McLean Model of Information Systems Success: A Ten-Year Update." Journal of Management Information Systems 19(4): 9-30.

Easterby-Smith, M., M. A. Lyles, et al. (2008). "Inter-Organizational Knowledge Transfer: Current Themes and Future Prospects." Journal of Management Studies 45(4): 677 690.

Folkens, F. and M. Spiliopoulou (2004). Towards an evaluation framework for knowledge management systems. International Conference on Practical Aspects of Knowledge Management, Vienna, Austria.

Foss, N. J. (2007). "The Emerging Knowledge Governance Approach: Challenges and Characteristics." Organization 14(1): 29-52.

Fuerst, W. L. and P. H. Cheney (1982). "Factors Affecting the Perceived Utilization of Computer-Based Decision Support Systems." Decision Sciences 13(4): 554-569.

Garrity, E. J., B. Glassberg, et al. (2005). "An experimental investigation of Web-based information systems success in the context of electronic commerce." Decision Support Systems 39(3): 485-503.

Gefen, D., D. Straub, et al. (2000). "Structural Equation Modeling and Regression: Guidelines for Research Practice." Communications of AIS 4(7): 1-80.

Gelderman, M. (1995). Factors affecting the success of management support systems: Analysis and meta-analysis. IS/MAS forum of the Annual Conference of the American Accounting Association. Orlando, FL.

Goodhue, D. L. and R. L. Thompson (1995). "Task-technology fit and individual performance." MIS Quarterly 19(2): 213-236.

Gray, P. H. and D. B. Meister (2006). "Knowledge sourcing methods." Information \& Management 43(2): 142-156.

Guimaraes, T. and M. Igbaria (1997). "Client/server system success: Exploring the human side." Decision Sciences 28(4): 851-876.

Hertzum, M. and A. M. Pejtersen (2000). "The information-seeking practices of engineers: searching for documents as well as for people." Information processing and Management 36(5): 761-778.

Holsapple, C. and J. Wu (2008). "In search of a missing link." Knowledge Management Research \& Practice 6(1): 31

Jennex, M. E. (2005). The Issue of System Use in Knowledge Management Systems. Annual Hawaii International Conference on System Sciences.

Jennex, M. E. and L. Olfman (2003). A Knowledge Management Success Model: An Extension of DeLone and McLean's IS Success Model. AMCIS.

Johnson, D. J. and L. L. Downing (1979). "Deindividuation and valence of cues: effects on prosocial and antisocial behavior." Journal of Personality and Social Psycology 37(9): $1532-1538$.

Juhani, I. (2005). "An empirical test of the DeLone-McLean model of information system success." SIGMIS Database 36(2): 8-27.

Kane, A. A., L. Argote, et al. (2005). "Knowledge transfer between groups via personnel rotation: Effects of social identity and knowledge quality." Organizational Behavior and Human Decision Processes 96(1): 56-71.

Kankanhalli, A. and B. C. Y. Tan (2004). A Review of Metrics for Knowledge Management Systems and Knowledge Management Initiatives. Hawaii International Conference on System Sciences.

King, W. R. and J. I. Rodriguez (1978). "Evaluating Management Information Systems." MIS Quarterly 2(3): 43-51.

King, W. R. and J. I. Rodriguez (1981). "Participative Design of Strategic Decision Support Systems." Management Science 27(6): 717-726.

Koeglreiter, G., R. Smith, et al. (2006). "The Role of Informal Groups in Organisational Knowledge Work: Understanding an Emerging Community of Practice." International Journal of Knowledge Management 2(1): 6 - 23. 
Kraaijenbrink, J. and F. Wijnhoven (2008). "Managing heterogeneous knowledge: a theory of external knowledge integration." Knowledge Management Research \& Practice 6(4): 274.

Krippendorff, K. (2004). Content analysis: an introduction to its methodology, Sage.

Leavitt, P. (2004). EXPERTISE LOCATOR SYSTEMS: FINDING THE ANSWERS Houston, Texas, USA, APQC.

Legris, P., J. Ingham, et al. (2003). "Why people use information technology? A critical review of the technology acceptance model." Information \& management 40: 191204.

Lesser, E. L. and J. Strock (2004). Overcoming Knowledge Barriers with Communities of Practice: Lessons Learned through Practical Experience. Knowledge Networks: Innovation through Communities of Practice. P. M. Hildreth and C. Kimble. Hershey, Idea Group Publishing: 14-23.

Lewins, A. and S. Christina (2005). Choosing a CAQDAS package. Surrey, UK, CAQDAS Networking project.

Lindsey, K. (2002). Measuring Knowledge Management Effectiveness: A Task-Contingent Organizational Capabilities Perspective. Americas Conference on Information Systems: 2085-2090.

Liu, S. C., L. Olfman, et al. (2005). "Knowledge Management System Success: Empirical Assessment of a Theoretical Model." International Journal of Knowledge Management 1(2): 68 - 87.

Lucas, H. C. J. (1975). "Performance and the Use of Information Systems." Management Science 21(8): 908-919.

Lucas, H. C. J. (1978). "Empirical Evidence for a Descriptive Model of Implementation." MIS Quarterly 2(2): 27-41.

Maier, R. (2002). Knowledge management systems. Berlin, Springer.

Maish, A. M. (1979). "A User's Behavior Toward His MIS." MIS Quarterly 3(1): 39-52.

Markus, M. L. (2001). "Toward a theory of knowledge reuse: types of knowledge reuse situations and factors in reuse success." Journal of Management Information Systems 18(1): 57-93.

Martin, J. (2006). "Multiple intelligence theory, knowledge identification and trust." Knowledge Management Research \& Practice 4(3): 207.

Mason, R. O. (1978). "Measuring information output: a communication systems approach." Information \& management 1(5): 219-234.

Massey, A. P., M. M. Montoya-Weiss, et al. (2002). "Knowledge Management in Pursuit of Performance: Insights from Nortel Networks." MIS Quarterly 26(3): 269-289.

Mathes, A. W. and T. A. Guest (1976). "Anonymity and group antisocial behaviour." Journal of Social Psychology 100: 257-262.

Mirani, R. and A. L. Lederer (1998). "An Instrument for Assessing the Organizational Benefits of IS Projects." Decision Sciences 29(4): 803-838.

Mutschler, B., M. U. Reichert, et al. (2008). "Unleashing the Effectiveness of Processoriented Information Systems: Problem Analysis, Critical Success Factors, Implications." IEEE Transactions on Systems, Man and Cybernetics 38(3): 280-291.

Myers, M. D. (2004). "Qualitative Research in Information Systems." MIS Quarterly 21(2): 241-242.

Nadler, A., M. Goldbert, et al. (1982). "Effect of self-differentiation and anonymity in group on deindividuation." Journal of Personality and Social Psycology 42(6): 1126-1136.

Nevo, D. and Y. E. Chan (2007). "A Delphi study of knowledge management systems: Scope and requirements." Information \& Management 44(6): 583-597.

Palvia, P., P. Pinjani, et al. (2007). "A profile of information systems research published in Information \& Management." Information \& Management 44(1): 1-11.

Parasuraman, A., V. A. Zeithaml, et al. (1988). "SERVQUAL: A Multiple-Item Scale for Measuring Consumer Perceptions of Service Quality." Journal of Retailing 64(1): 1240. 
Pavlou, P. A. and A. Dimoka (2006). "The Nature and Role of Feedback Text Comments in Online Marketplaces: Implications for Trust Building, Price Premiums, and Seller Differentiation." Information Systems Research 17(4): 392-414.

Petter, S., W. DeLone, et al. (2008). "Measuring information systems success: models, dimensions, measures, and interrelationships." European Journal of Information System 17(3): 236-263.

Pinsonneault, A. and N. Heppel (1997-8). "Anonymity in Group Support Systems Research: A New Conceptualization, Measure, and Contingency Framework." Journal of Management Information Systems 14(3): 89-108.

Pitt, L. F., R. T. Watson, et al. (1995). "Service quality: a measure of information systems effectiveness." MIS Quarterly 19(2): 173-188.

Propst, L. R. (1979). "Effects of personality and loss of anonymity on aggregation: a reevaluation of deindividuation." Journal of Personality 47(3): 531-544.

Qian, Z. and G.-W. Bock (2005). An Empirical Study on Measuring the Success of Knowledge Repository Systems. Annual Hawaii International Conference on System Sciences.

Rai, A., S. S. Lang, et al. (2002). "Assessing the validity of IS success models: an empirical test and theoretical analysis." Information systems research 13(1): 50-59.

Raymond, L. (1985). "Organizational Characteristics and MIS Success in the Context of Small Business." MIS Quarterly 9(1): 37-52.

Reichling, T., M. Veith, et al. (2007). "Expert Recommender: Designing for a Network Organization." Comput. Supported Coop. Work 16(4-5): 431-465.

Rosendaal, B. (2009). "Sharing knowledge, being different and working as a team." Knowledge Management Research \& Practice 7(1): 4.

Sabherwal, R., A. Jeyaraj, et al. (2006). "Information System Success: Individual and Organizational Determinants." Management science 52(12): 1849-1864.

Schwartz, D. (2007). "Integrating knowledge transfer and computer-mediated communication: categorizing barriers and possible responses." Knowledge Management Research \& Practice 5(4): 249.

Seddon, P. B. (1997). "A respecification and extension of the DeLone and McLean model of IS success." Information Systems Research 8(3): 240-253.

Shannon, C. E. and W. Warren (1949). The mathematical theory of communication. Urbana, Illinois, USA, University of Illinois Press.

Solomon, H., L. Z. Solomon, et al. (1982). "The effects of bystander's anonymity, situational ambiguity, and victim's status on helping." Journal of Social Psychology 117: 285294.

Spohrer, J. and D. Riecken (2006). "Services science." Communications of the ACM 49(7): 30-32.

Spreng, R. A. and R. D. Mackoy (1996). "An Empirical Examination of a Model of Perceived Service Quality and Satisfaction." Journal of Retailing 72(2): 201-215.

Straub, D., D. Gefen, et al. (2006). "Quantitative, positivist research methods in Information Systems." Retrieved 24/05/2006, 2006, from http://dstraub.cis.gsu.edu:88/quant/.

Straub, D. W., M.-C. Boudreau, et al. (2004). "Validation Guidelines for IS Positivist Research." Communications of the AIS 13(24): 50.

Swanson, E. B. (1974). "Management Information Systems: Appreciation and Involvement." Management Science 21(2): 178-188.

Taylor, S. and P. A. Todd (1995). "Understanding information technology usage : a test of competing models." Information Systems Research 6(2): 144-176.

Venkatesh, V. (2000). "Determinants of Perceived Ease of Use: Integrating Control, Intrinsic Motivation, and Emotion into the Technology Acceptance Model." Information systems research 11(4): 342-366.

Vitari, C., J. Moro, et al. (2006). "Improving KMS Acceptance: The Role Of Organizational And Individuals' Influence." International Journal Knowledge Management 3(2).

Wang, J.-K., M. Ashleigh, et al. (2006). "Knowledge sharing and team trustworthiness: it's all about social ties!" Knowledge Management Research \& Practice 4(3): 175. 
Wijk, R. v., J. J. P. Jansen, et al. (2008). "Inter- and Intra-Organizational Knowledge Transfer: A Meta-Analytic Review and Assessment of its Antecedents and Consequences." Journal of Management Studies 45(4): 830-853.

Wu, J.-H. and Y.-M. Wang (2006). "Measuring KMS success: A respecification of the DeLone and McLean's model." Information \& Management 43(6): 728-739.

Yimam-Seid, D. and A. Kobsa (2000). Centralization vs. Decentralization Issues in Internetbased Knowledge Management Systems: Experiences from Expert Recommender Systems. Workshop on Organizational and Technical Issues in the Tension Between Centralized and Decentralized Applications on the Internet, University of California Software Institute, Irvine, CA.

Yin, R. K. (2002). Case study research: design and methods. Thousand Oaks, California, USA, Sage Publications.

Yoon, Y. and T. Guimaraes (1995). "Assessing expert systems impact on users' jobs." Journal of Management Information Systems 12(1): 225-249.

Younbok, L. and C. Ho-Jin (2005). Experience of Combining Qualitative and Quantitative Analysis Methods for Evaluating Software Architecture. Proceedings of the Fourth Annual ACIS International Conference on Computer and Information Science, IEEE Computer Society.

Zviran, M. and Z. Erlich (2003). "Measuring IS user satisfaction: review and implications." Communications of the AIS 12: 81-105.

\section{Annexes}

\begin{tabular}{|c|c|c|c|c|}
\hline & MODEL & $\begin{array}{l}\text { Technology } \\
\text { Acceptance } \\
\text { Model }\end{array}$ & $\begin{array}{l}\text { DeLone and } \\
\text { McLean's IS } \\
\text { Success Model }\end{array}$ & $\begin{array}{l}\text { Seddon's IS Success } \\
\text { Model }\end{array}$ \\
\hline \multirow{2}{*}{$\begin{array}{l}\text { TYPES OF IS } \\
\text { (computer-based, } \\
\text { paper-based, and } \\
\text { informal } \\
\text { systems) }\end{array}$} & $\begin{array}{l}\text { Original } \\
\text { model }\end{array}$ & $\begin{array}{l}\text { Specifically } \\
\text { developed for } \\
\text { computer-based IS. }\end{array}$ & $\begin{array}{l}\text { Conceived for computer- } \\
\text { based IS. }\end{array}$ & $\begin{array}{l}\text { Extensibility of the model } \\
\text { also to paper-based and } \\
\text { informal IS. }\end{array}$ \\
\hline & Extensions & $\begin{array}{l}\text { It remains mainly } \\
\text { focused on } \\
\text { computer-based IS } \\
\text { (Legris, Ingham et } \\
\text { al. 2003), but it } \\
\text { includes also } \\
\text { applications on } \\
\text { formal IS, not } \\
\text { completely } \\
\text { computer-based } \\
\text { (Taylor and Todd } \\
\text { 1995) }\end{array}$ & $\begin{array}{l}\text { It is applied also to the } \\
\text { IS departments, in } \\
\text { charge of the delivery of } \\
\text { information through: } \\
\text { formal computer-based, } \\
\text { formal paper-based and } \\
\text { informal IS (Pitt, Watson } \\
\text { et al. 1995; Jennex } \\
\text { 2005) }\end{array}$ & $\begin{array}{l}\text { The author affirms the } \\
\text { extensibility of the model } \\
\text { to paper-based IS and } \\
\text { informal IS, but there is } \\
\text { no empirical test in these } \\
\text { contexts }\end{array}$ \\
\hline \multirow[t]{2}{*}{$\begin{array}{l}\text { DIMENSIONS OF } \\
\text { THE SUCCESS } \\
\text { (inclusion of the } \\
\text { services } \\
\text { provided by the } \\
\text { system) }\end{array}$} & $\begin{array}{l}\text { Original } \\
\text { model }\end{array}$ & $\begin{array}{l}\text { It measures } \\
\text { acceptance as } \\
\text { dimension of IS } \\
\text { success, only } \\
\text { through the degree } \\
\text { of IS use. }\end{array}$ & $\begin{array}{l}\text { It considers the } \\
\text { multidimensionality of } \\
\text { the IS success, including } \\
\text { IS use, but excluding } \\
\text { Service Quality. }\end{array}$ & $\begin{array}{l}\text { It considers the } \\
\text { multidimensionality of the } \\
\text { IS success, but IS use } \\
\text { and Service Quality are } \\
\text { excluded, but the author } \\
\text { affirms the admissibility of } \\
\text { Service Quality, on case } \\
\text { basis. }\end{array}$ \\
\hline & Extensions & $\begin{array}{l}\text { IS use, self- } \\
\text { reported or } \\
\text { objective, remains } \\
\text { the dependent } \\
\text { variable (Legris, } \\
\text { Ingham et al. 2003) }\end{array}$ & $\begin{array}{l}\text { Service Quality is } \\
\text { included as IS success } \\
\text { dimension (Pitt, Watson } \\
\text { et al. 1995; DeLone and } \\
\text { McLean 2003; Jennex } \\
\text { 2005) }\end{array}$ & $\begin{array}{l}\text { Use and Intention to Use } \\
\text { remain excluded from the } \\
\text { IS success. Non- } \\
\text { directional path between } \\
\text { Perceived Usefulness and } \\
\text { Use is proposed (Rai, } \\
\text { Lang et al. 2002). The } \\
\text { inclusion of Use in the } \\
\text { Success model is } \\
\text { reaffirmed by } \\
\text { Delone and McLean } \\
\text { (DeLone and McLean }\end{array}$ \\
\hline
\end{tabular}




\begin{tabular}{|l|l|l|l|l|}
\hline & & & $2003)$ \\
\hline $\begin{array}{l}\text { CONTEXTS OF } \\
\text { APPLICABILITY } \\
\text { (volitional or } \\
\text { non-volitional IS } \\
\text { use) }\end{array}$ & $\begin{array}{l}\text { Original } \\
\text { model }\end{array}$ & $\begin{array}{l}\text { The model is } \\
\text { defined for non } \\
\text { volitional IS use }\end{array}$ & $\begin{array}{l}\text { The model is defined for } \\
\text { non volitional IS use }\end{array}$ & $\begin{array}{l}\text { The model can be applied } \\
\text { to volitional and non } \\
\text { volitional IS use }\end{array}$ \\
\cline { 2 - 5 } & Extensions & $\begin{array}{l}\text { Applicability is } \\
\text { extended also to } \\
\text { volitional IS use } \\
\text { contexts (Taylor } \\
\text { and Todd 1995; } \\
\text { Venkatesh 2000) }\end{array}$ & $\begin{array}{l}\text { Applicability is extended } \\
\text { also to volitional IS use } \\
\text { contexts (Rai, Lang et al. } \\
2002)\end{array}$ & $\begin{array}{l}\text { The model was already } \\
\text { applicable to both } \\
\text { volitional and non } \\
\text { volitional IS }\end{array}$ \\
\hline
\end{tabular}

models 


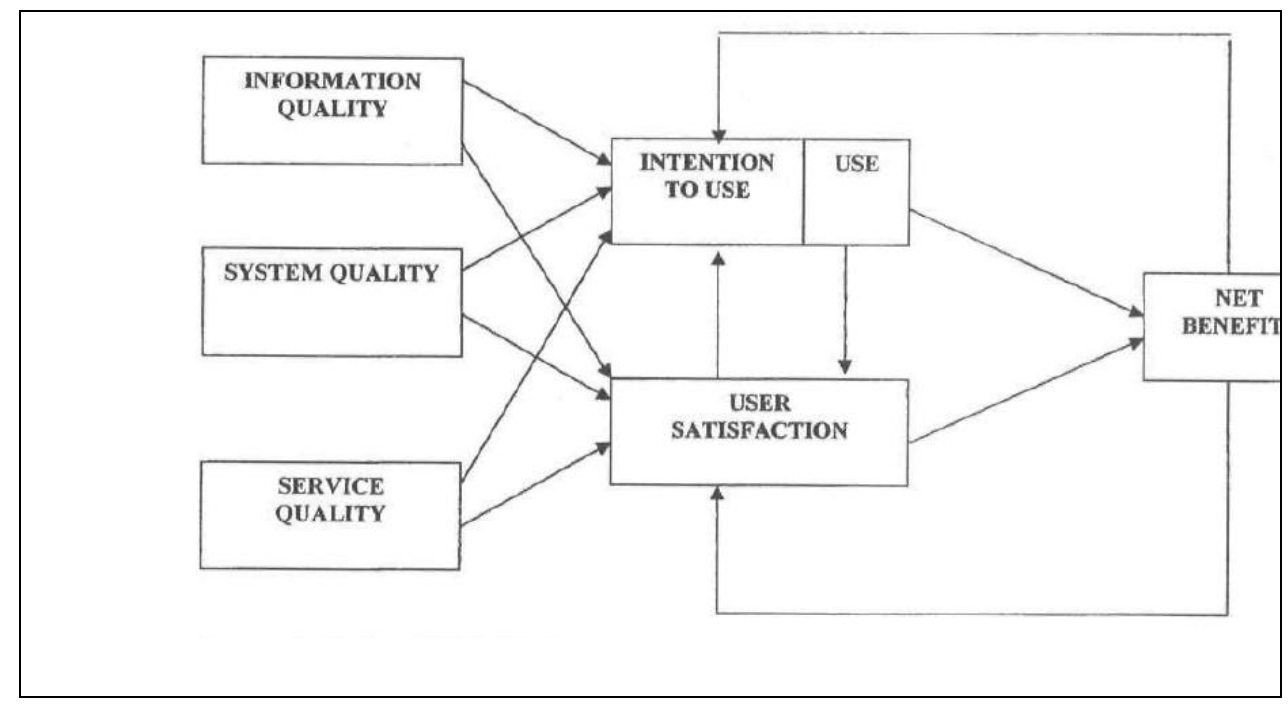

Figure 1 The updated DeLone and McLean's IS Success Model (2003) 


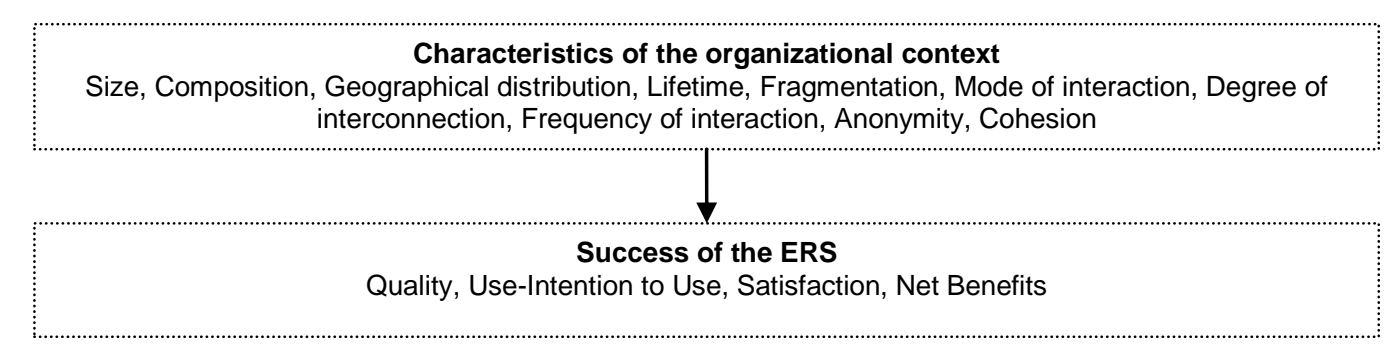

Figure 2 The explorative model

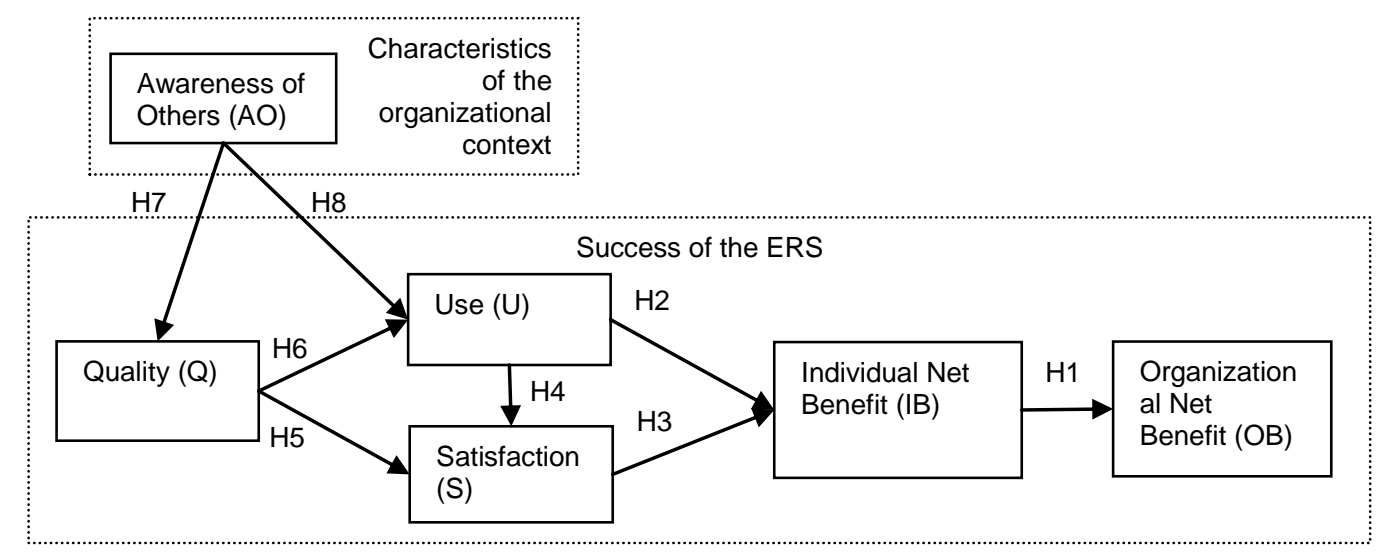

Figure 3 The confirmatory model 


\begin{tabular}{|c|c|c|c|c|c|}
\hline Case & NSS & MM & FST & ESCC & BESR \\
\hline $\begin{array}{r}\text { Orga } \\
\text { nization type }\end{array}$ & Multinational corporation & $\begin{array}{l}\text { Three business schools } \\
\text { with their respective research } \\
\text { centers }\end{array}$ & Multinational corporation & $\begin{array}{l}\text { Multinational } \\
\text { corporation }\end{array}$ & $\begin{array}{l}\text { Multinational } \\
\text { corporation }\end{array}$ \\
\hline $\begin{array}{r}\text { Main } \\
\text { activity sector }\end{array}$ & $\begin{array}{l}\text { Information Technology } \\
\text { services and solutions }\end{array}$ & $\begin{array}{l}\text { Teaching and research in } \\
\text { management }\end{array}$ & $\begin{array}{l}\text { Pneumatic products, } \\
\text { solutions, and services }\end{array}$ & $\begin{array}{l}\text { Electrical and } \\
\text { electronic products }\end{array}$ & $\begin{array}{c}\text { Small } \\
\text { household appliances }\end{array}$ \\
\hline I revenue & $\$ 5.800$ million in 2005 & Not relevant & $€ 1.400$ million in 2005 & $€ 12.000$ million in & $\begin{array}{c}€ 2600 \\
\text { million in } 2005\end{array}$ \\
\hline $\begin{array}{c}\text { Empl } \\
\text { oyee number }\end{array}$ & 37.000 & 500 & 10.000 & 90.000 & 14.000 \\
\hline $\begin{array}{l}\text { Globa } \\
\text { I geographical } \\
\text { distribution }\end{array}$ & Worldwide & In the same French town & Worldwide & Worldwide & Worldwide \\
\hline $\begin{array}{l}\text { Orga } \\
\text { nizational } \\
\text { section } \\
\text { examined }\end{array}$ & Italian subsidiary & Consortium in the making & Italian subsidiary & $\begin{array}{l}\text { Hotline and technical } \\
\text { assistance department }\end{array}$ & $\begin{array}{l}\text { Research } \\
\text { department }\end{array}$ \\
\hline $\begin{array}{l}\text { Comp } \\
\text { uter-based } \\
\text { ERS }\end{array}$ & $\begin{array}{l}\text { The human resource management } \\
\text { module of the Enterprise Resource } \\
\text { Planning application and the } \\
\text { curriculum vitae repository are the } \\
\text { two mains components of the } \\
\text { computer-based ERS. Each } \\
\text { member of the organization updates } \\
\text { his curriculum vitae and his personal } \\
\text { profile in the human resource } \\
\text { management module. The } \\
\text { curriculum vitae update has no } \\
\text { constraints in the redaction format } \\
\text { except for the textual format file. } \\
\text { The personal profile filling is } \\
\text { compulsory every year and includes } \\
\text { information on career evolution, } \\
\text { personnel annual evaluation, } \\
\text { accomplished missions, projects, } \\
\text { training and previous positions. } \\
\text { The access to the ERS is limited } \\
\text { depending on the responsibility in } \\
\text { the organization. Human resource } \\
\text { staff has full access to all the } \\
\text { information of all the members of } \\
\text { the organization. The other } \\
\text { personnel have access only on the }\end{array}$ & $\begin{array}{l}\text { Different and not integrated } \\
\text { solutions exist in the different } \\
\text { research centers and business } \\
\text { schools: Excel tables and web sites } \\
\text { on the knowledge domains of the } \\
\text { members. The members of one } \\
\text { research center update their } \\
\text { profiles in an Excel table (one row } \\
\text { for each member), which is then } \\
\text { shared with the other members of } \\
\text { the research center. The members } \\
\text { of the other research centers } \\
\text { update their profile in a web page } \\
\text { which is published and visible on } \\
\text { the Internet. } \\
\text { In both cases, a description of the } \\
\text { research interests, the references } \\
\text { of the achieved publications and a } \\
\text { mini biography are stored. } \\
\text { Browsing and free keyword } \\
\text { searching in the text of the Excel } \\
\text { table and of the web site are the } \\
\text { two ways to retrieve experts. } \\
\text { The display of the experts is } \\
\text { performed through the proposal of } \\
\text { the cells of the Excel table or the }\end{array}$ & $\begin{array}{l}\text { The human resource management } \\
\text { module of the Enterprise Resource } \\
\text { Planning stores and makes } \\
\text { accessible the knowledge domains } \\
\text { of the members. } \\
\text { Each member of the organization } \\
\text { updates his personal profile in the } \\
\text { human resource management } \\
\text { module, reproducing his curriculum } \\
\text { vitae and his personnel annual } \\
\text { evaluations. } \\
\text { All the members can navigate in the } \\
\text { organizational chart, resulting from } \\
\text { the collected data on the actual job } \\
\text { positions of each member. All the } \\
\text { members can access to the contact } \\
\text { information of the employee } \\
\text { occupying the position and to some } \\
\text { general pieces of information } \\
\text { concerning the job description, in } \\
\text { terms of competences and main } \\
\text { activities required for the position. } \\
\text { Only managers can access the } \\
\text { detailed personnel curriculum vitae } \\
\text { and the personnel annual } \\
\text { evaluations of the respective }\end{array}$ & $\begin{array}{l}\text { The Customer } \\
\text { Relationship Management } \\
\text { application and the KMS are the } \\
\text { two components of the ERS. } \\
\quad \text { The Customer } \\
\text { Relationship Management } \\
\text { application automatically stores } \\
\text { all the written answers that each } \\
\text { member has given to the } \\
\text { customers. } \\
\quad \text { In the KMS the } \\
\text { members upload the technical } \\
\text { product files whom they are } \\
\text { author. This technical product } \\
\text { files include the name and } \\
\text { contact information of their } \\
\text { technical editors and of their } \\
\text { business approvers. } \\
\quad \text { All the members can } \\
\text { access the Customer } \\
\text { Relationship Management } \\
\text { application to browse the } \\
\text { answers to the customers or to } \\
\text { search using free keywords the } \\
\text { members who have use the } \\
\text { searched keyword in their }\end{array}$ & $\begin{array}{l}\text { The Internal } \\
\text { Expertise application } \\
\text { accessible from the } \\
\text { intranet is the main } \\
\text { component of the } \\
\text { ERS. This application } \\
\text { stored the curriculum } \\
\text { vitae of all the } \\
\text { members. } \\
\text { Each member of the } \\
\text { organization updates } \\
\text { his curriculum vitae in } \\
\text { the Internal Expertise } \\
\text { application. The } \\
\text { curriculum vitae } \\
\text { update has no } \\
\text { constraints in the } \\
\text { redaction format, with } \\
\text { the exception of the } \\
\text { textual format file. } \\
\text { The } \\
\text { curriculum vitae can be } \\
\text { browsed or retrieved } \\
\text { through a textual } \\
\text { search engine using } \\
\text { free keywords by all }\end{array}$ \\
\hline
\end{tabular}




\begin{tabular}{|c|c|c|c|c|}
\hline $\begin{array}{l}\text { information on the respective } \\
\text { subordinates. } \\
\text { Browsing and searching in the } \\
\text { curriculum vitae repository and in } \\
\text { the human resources management } \\
\text { module are the two functionalities to } \\
\text { retrieve experts. The search in the } \\
\text { curriculum vitae repository is } \\
\text { through free keywords and the } \\
\text { search is textual on the curriculum } \\
\text { vitae. The curriculum vitae having } \\
\text { the searched keywords will be } \\
\text { displayed. The search in the human } \\
\text { resources management module can } \\
\text { be run field by field or combining } \\
\text { several criteria and several fields } \\
\text { together. The profile of the members } \\
\text { matching the search criteria will be } \\
\text { displayed }\end{array}$ & $\begin{array}{l}\text { listing of the web pages containing } \\
\text { the searched keywords. }\end{array}$ & subordinates. & $\begin{array}{l}\text { answers to the clients. The } \\
\text { application recommends a list of } \\
\text { experts based on the analysis } \\
\text { of the answers of the members } \\
\text { to the clients stored in the } \\
\text { application. } \\
\text { All the members can } \\
\text { also access the KMS to browse } \\
\text { or search through the technical } \\
\text { product files. The system } \\
\text { recommends a list of experts } \\
\text { based on the analysis of the } \\
\text { authorship of the technical } \\
\text { product files. }\end{array}$ & $\begin{array}{l}\text { the members. } \\
\text { The full } \\
\text { curriculum vitae } \\
\text { containing the } \\
\text { searched keywords will } \\
\text { be displayed. }\end{array}$ \\
\hline
\end{tabular}

Table 2: The 5 case organizations 


\begin{tabular}{|c|c|}
\hline Awareness of Others (AO) & \\
\hline The colleagues know the knowledge domains where I have competencies. & \multirow{7}{*}{ Strongly disagree....strongly agree. } \\
\hline $\begin{array}{l}\text { Throughout the colleagues, everyone knows who the experts are in the } \\
\text { different knowledge domains. }\end{array}$ & \\
\hline $\begin{array}{l}\text { I have a specialization that allows me being recognized, among the } \\
\text { colleagues, as qualified in certain knowledge domains. }\end{array}$ & \\
\hline $\begin{array}{l}\text { It is possible to identify the experts in the different knowledge domains, } \\
\text { among the colleagues. }\end{array}$ & \\
\hline $\begin{array}{l}\text { I can recognize the experts in the different knowledge domains, among the } \\
\text { colleagues. }\end{array}$ & \\
\hline The colleagues recognize me as qualified in certain knowledge domains. & \\
\hline $\begin{array}{l}\text { The colleagues recognize the knowledge domains where the colleagues } \\
\text { have competences. }\end{array}$ & \\
\hline \multicolumn{2}{|l|}{ Quality (Q) } \\
\hline \multirow{3}{*}{$\begin{array}{l}\text { Overall, what is the quality of the answers to your demands for } \\
\text { recommending an expert? }\end{array}$} & very low/very high. \\
\hline & awful/excellent. \\
\hline & extremely poor/extremely good. \\
\hline \multicolumn{2}{|l|}{ Use (U) } \\
\hline I demand for recommending experts all the time. & Strongly disagree....strongly agree. \\
\hline My current demands for recommending experts are: & very infrequent/very frequent. \\
\hline \multicolumn{2}{|l|}{ Satisfaction (S) } \\
\hline \multirow{4}{*}{ About the answers to my demands for recommending experts, I am: } & $\begin{array}{l}\text { Extremely terrible... extremely } \\
\text { delighted. }\end{array}$ \\
\hline & $\begin{array}{l}\text { Extremely dissatisfied...extremely } \\
\text { satisfied. }\end{array}$ \\
\hline & $\begin{array}{l}\text { Extremely frustrated... extremely } \\
\text { contented. }\end{array}$ \\
\hline & $\begin{array}{l}\text { Extremely displeased... extremely } \\
\text { pleased. }\end{array}$ \\
\hline \multicolumn{2}{|l|}{ Individual Net Benefit (IB) } \\
\hline Demanding for recommending experts improves my performance. & \multirow{3}{*}{ Strongly disagree....strongly agree } \\
\hline Demanding for recommending experts enhances my effectiveness. & \\
\hline Demanding for recommending experts increases my productivity. & \\
\hline \multicolumn{2}{|l|}{ Organizational Net Benefit (OB) } \\
\hline $\begin{array}{l}\text { In general in the organization, the demands for recommending experts } \\
\text { enable faster retrieval of information. }\end{array}$ & \multirow[b]{2}{*}{ Strongly disagree...strongly agree. } \\
\hline $\begin{array}{l}\text { In general in the organization, the demands for recommending experts } \\
\text { enable easier access to information. }\end{array}$ & \\
\hline
\end{tabular}

Table 3 Questionnaire for the confirmatory quantitative method, with the items on the left and the answers' scales on the right 


\begin{tabular}{|c|c|c|c|c|c|}
\hline Cases & NSS & MM & FST & ESCC & BESR \\
\hline Size & 550 & 210 & 180 & 100 & 150 \\
\hline Composition & $\begin{array}{l}\text { The employees work on } \\
\text { different business sectors and } \\
\text { in different markets, so the } \\
\text { portion of common } \\
\text { knowledge is reduced. }\end{array}$ & $\begin{array}{l}\text { The involvement in research } \\
\text { or in teaching activities on } \\
\text { management is the common } \\
\text { denomination among the } \\
\text { members. Beyond this } \\
\text { communality, they could be } \\
\text { members of different } \\
\text { organizations, and they could } \\
\text { have different educational } \\
\text { background. }\end{array}$ & $\begin{array}{l}\text { The sector of activity is the } \\
\text { same for all the employees, } \\
\text { but there are differences in } \\
\text { terms of individual functions, } \\
\text { from teaching to accounting, } \\
\text { from sales to customer } \\
\text { service }\end{array}$ & $\begin{array}{l}\text { High portion of common } \\
\text { technical knowledge about } \\
\text { the products of the } \\
\text { corporation. At each location, } \\
\text { the employees have } \\
\text { developed a specific technical } \\
\text { code that is different in the } \\
\text { two sites }\end{array}$ & $\begin{array}{l}\text { All the employees are } \\
\text { engineers and have a portion } \\
\text { of common knowledge on } \\
\text { house appliances } \\
\text { development }\end{array}$ \\
\hline $\begin{array}{l}\text { Geographical } \\
\text { distribution }\end{array}$ & $\begin{array}{l}\text { The members are distributed } \\
\text { in three different locations } \\
\text { and in each location there are } \\
\text { employees of each sector } \\
\text { and market }\end{array}$ & $\begin{array}{l}\text { There are three different } \\
\text { locations in the same town for } \\
\text { the three business schools } \\
\text { and research centers. But } \\
\text { some members have } \\
\text { teaching and research } \\
\text { activities in other towns }\end{array}$ & $\begin{array}{l}\text { The organization has five } \\
\text { locations and the employees } \\
\text { of the same business unit are } \\
\text { distributed across them }\end{array}$ & $\begin{array}{l}\text { The employees are } \\
\text { distributed in two locations in } \\
\text { two different French towns }\end{array}$ & $\begin{array}{l}\text { The researchers are } \\
\text { distributed in four locations in } \\
\text { France, one in Germany and } \\
\text { one in Brazil }\end{array}$ \\
\hline Lifetime & $\begin{array}{l}\text { In the '90s, an organizational } \\
\text { restructure determined the } \\
\text { reconfiguration of the } \\
\text { organization in new business } \\
\text { units and the internal } \\
\text { movement of the employees }\end{array}$ & $\begin{array}{l}\text { A radical organizational } \\
\text { reconfiguration is in progress } \\
\text { due to the start-up of the } \\
\text { consortium among the } \\
\text { business schools and the } \\
\text { research centers. }\end{array}$ & $\begin{array}{l}\text { In the '90s the production } \\
\text { facility has been suppressed } \\
\text { and the education business } \\
\text { has been developed which } \\
\text { included a radical } \\
\text { organizational restructuring. }\end{array}$ & $\begin{array}{l}\text { Two complementary radical } \\
\text { organizational } \\
\text { reconfigurations recently took } \\
\text { place. In } 2000 \text { all the } \\
\text { employees have been } \\
\text { grouped in only two locations. } \\
\text { In } 2002 \text { a new type of job } \\
\text { position has been created } \\
\text { and it imposes a complete } \\
\text { reorganization of the } \\
\text { employees }\end{array}$ & $\begin{array}{l}\text { In } 2000 \text { the last } \\
\text { reconfiguration of the } \\
\text { research department took } \\
\text { place after the merger with } \\
\text { another research department }\end{array}$ \\
\hline Fragmentation & $\begin{array}{l}\text { The main fragmentation of } \\
\text { the personnel is in sectors } \\
\text { and in markets. }\end{array}$ & $\begin{array}{l}\text { The organization is } \\
\text { fragmented in different } \\
\text { intersecting groups, each one } \\
\text { specialized in a teaching or } \\
\text { research subject or gathering } \\
\text { people of the same business } \\
\text { school or of the same } \\
\text { research centre. }\end{array}$ & $\begin{array}{l}\text { The main fragmentation of } \\
\text { the personnel is in functional } \\
\text { units. }\end{array}$ & $\begin{array}{l}\text { The personnel are } \\
\text { fragmented in two poles of } \\
\text { competencies: one on } \\
\text { automatism and the other on } \\
\text { process control. }\end{array}$ & $\begin{array}{l}\text { The personnel is fragmented } \\
\text { on three product lines and } \\
\text { two technological domains }\end{array}$ \\
\hline $\begin{array}{l}\text { Mode of } \\
\text { interaction }\end{array}$ & $\begin{array}{l}\text { The most of the interactions } \\
\text { are face to face or by mobile } \\
\text { phone. The email and the } \\
\text { fixed phones are quite } \\
\text { secondary. }\end{array}$ & $\begin{array}{l}\text { The interactions take place } \\
\text { mainly through face to face } \\
\text { communications or via email. } \\
\text { Some other used } \\
\text { communication tools are the } \\
\text { telephone and the instant } \\
\text { messaging. }\end{array}$ & $\begin{array}{l}\text { The interactions are face to } \\
\text { face or by telephone and } \\
\text { Lotus Notes application, } \\
\text { especially for the employees } \\
\text { temporarily outside the } \\
\text { organization. }\end{array}$ & $\begin{array}{l}\text { The interactions are mainly } \\
\text { face to face (around } 80 \% \text { ) } \\
\text { and by the email (around } \\
20 \% \text { ) }\end{array}$ & $\begin{array}{l}\text { The interactions are face to } \\
\text { face or mainly by email or } \\
\text { telephone. }\end{array}$ \\
\hline $\begin{array}{l}\text { Degree of } \\
\text { interconnection }\end{array}$ & $\begin{array}{l}\text { The majority of interactions } \\
\text { are between peers or } \\
\text { between the superior and his }\end{array}$ & $\begin{array}{l}\text { The majority of interactions } \\
\text { are between peers, during the } \\
\text { informal meeting, or }\end{array}$ & $\begin{array}{l}\text { The majority of the } \\
\text { interactions are personal, } \\
\text { while another part of the }\end{array}$ & $\begin{array}{l}\text { The majority of the } \\
\text { interactions are personal, } \\
\text { while another part of the }\end{array}$ & $\begin{array}{l}\text { The interactions are mainly } \\
\text { interpersonal or within project } \\
\text { teams. Nevertheless, a big }\end{array}$ \\
\hline
\end{tabular}




\begin{tabular}{|c|c|c|c|c|c|}
\hline & subordinate. & $\begin{array}{l}\text { assembly interactions, during } \\
\text { the formal group meetings. }\end{array}$ & $\begin{array}{l}\text { interactions involve the whole } \\
\text { selling team or the whole } \\
\text { organization. }\end{array}$ & $\begin{array}{l}\text { interactions are openly } \\
\text { launched at all the members }\end{array}$ & $\begin{array}{l}\text { portion of interactions are } \\
\text { organization-wide, when a } \\
\text { researcher wishes to mobilize } \\
\text { ideas on how to solve a } \\
\text { specific problem and at the } \\
\text { annual forum meeting. }\end{array}$ \\
\hline $\begin{array}{l}\text { Frequency of } \\
\text { interaction }\end{array}$ & $\begin{array}{l}\text { The interactions are frequent } \\
\text { within the members of the } \\
\text { same business unit. }\end{array}$ & $\begin{array}{l}\text { The interactions depend } \\
\text { largely on the individual } \\
\text { attitude. Some members } \\
\text { interact intensively, while } \\
\text { others are largely } \\
\text { autonomous and } \\
\text { independent. }\end{array}$ & $\begin{array}{l}\text { The frequency of interaction } \\
\text { is high between members of } \\
\text { the same team, the superior } \\
\text { and his subordinate, and the } \\
\text { employees on the same } \\
\text { business process }\end{array}$ & $\begin{array}{l}\text { The interactions within the } \\
\text { same location take place } \\
\text { continuously, as employees } \\
\text { contact the colleagues about } \\
\text { clients' needs. On the } \\
\text { opposite the interactions } \\
\text { between the two locations are } \\
\text { less frequent. }\end{array}$ & $\begin{array}{l}\text { The frequency of interaction } \\
\text { is high but irregular } \\
\text { depending on the stage and } \\
\text { kind of research project the } \\
\text { researchers are working on, } \\
\text { but a high in the frequency of } \\
\text { interactions is achieved } \\
\text { during the annual forum } \\
\text { meeting. }\end{array}$ \\
\hline Anonymity & $\begin{array}{l}\text { There is not anonymity and } \\
\text { there is a quite well } \\
\text { acknowledgement of the } \\
\text { other members }\end{array}$ & $\begin{array}{l}\text { There is not anonymity but in } \\
\text { many cases the members } \\
\text { have not a clear } \\
\text { understanding of the } \\
\text { knowledge domains of the } \\
\text { other members }\end{array}$ & $\begin{array}{l}\text { There is not anonymity and in } \\
\text { general a good } \\
\text { comprehension of the } \\
\text { knowledge of the other } \\
\text { members }\end{array}$ & $\begin{array}{l}\text { There is not anonymity but } \\
\text { there is a heterogeneous } \\
\text { degree of acknowledgement } \\
\text { of the other members. The } \\
\text { acknowledgement is high for } \\
\text { the personnel in the same } \\
\text { location, and low for the } \\
\text { personnel in the other } \\
\text { location }\end{array}$ & $\begin{array}{l}\text { There is not anonymity but } \\
\text { there is an heterogeneous } \\
\text { degree of acknowledgement } \\
\text { of the other members and } \\
\text { knowledge domains evolve } \\
\text { rapidly }\end{array}$ \\
\hline Cohesion & $\begin{array}{l}\text { The cohesion exists among } \\
\text { the members in each } \\
\text { business unit, while the } \\
\text { cohesion is weak between } \\
\text { employees across different } \\
\text { business units. }\end{array}$ & $\begin{array}{l}\text { The cohesion is growing } \\
\text { thanks to the intervention of } \\
\text { the deans and of the } \\
\text { directors. Nevertheless, there } \\
\text { are some frictions and some } \\
\text { conflicts between the } \\
\text { research centers and } \\
\text { between the business } \\
\text { schools, caused by a spirit of } \\
\text { competition existing among } \\
\text { them. }\end{array}$ & $\begin{array}{l}\text { A significant cohesion seems } \\
\text { to exist among the } \\
\text { employees, even if some } \\
\text { conflicts are evident and the } \\
\text { annual survey reveals also } \\
\text { some negative aspects on the } \\
\text { personnel cohesion. }\end{array}$ & $\begin{array}{l}\text { A high degree of cohesion } \\
\text { seems pervading the } \\
\text { organization: many } \\
\text { employees have extra- } \\
\text { professional relationships } \\
\text { together and this cohesion } \\
\text { has been built at the time of } \\
\text { the grouping of all the } \\
\text { employees in only two } \\
\text { locations }\end{array}$ & $\begin{array}{l}\text { A high degree of cohesion } \\
\text { seems existing in the } \\
\text { organization, based on the } \\
\text { success of the annual forum } \\
\text { meeting }\end{array}$ \\
\hline
\end{tabular}

Table 4 Characteristics of the organizational context of the five cases 
Discriminant validity: the comparison of the $x 2$

\begin{tabular}{|l|l|l|l|l|l|}
\hline Model & NPAR & CMIN & DF & P & CMIN/DF \\
\hline Default model & 42 & 174,121 & 111 & 0,000 & 1,569 \\
\hline Saturated model & 153 & 0,000 & 0 & & \\
\hline Independence model & 17 & 3034,897 & 136 & 0,000 & 22,315 \\
\hline
\end{tabular}

\section{Table 5 The construct validity}

Internal Consistency: Cronbach's a

\begin{tabular}{|l|l|}
\hline & Cronbach's a \\
\hline Individual Net Benefit (IB) & 0,851 \\
\hline Awareness of Others (AO) & 0,825 \\
\hline Quality (Q) & 0,715 \\
\hline Organizational Net Benefit (OB) & 0,857 \\
\hline Satisfaction (S) & 0,935 \\
\hline Use (U) & 0,728 \\
\hline
\end{tabular}

Convergent and factorial validity: the NFI, GFI, AGFI

\begin{tabular}{|l|lll|}
\hline Model & NFI (Delta1) & GFI & AGFI \\
\hline Default model & 0,943 & 0,929 & 0,902 \\
\hline
\end{tabular}

Split Half: correlation

\begin{tabular}{|l|l|l|l|}
\hline Construct & $\begin{array}{l}\text { First } \\
\text { sub- } \\
\text { scale }\end{array}$ & $\begin{array}{l}\text { Second } \\
\text { sub-scale }\end{array}$ & $\begin{array}{l}\text { Correlation } \\
\text { between forms }\end{array}$ \\
\hline $\begin{array}{l}\text { Awareness of Others } \\
(\mathrm{AO})\end{array}$ & 1,2 & 4,3 & 0,688 \\
\hline Quality (Q) & 1 & 2 & 0,558 \\
\hline $\begin{array}{l}\text { Individual Net } \\
\text { Benefit (IB) }\end{array}$ & 2,3 & 1 & 0737 \\
\hline $\begin{array}{l}\text { Organizational Net } \\
\text { Benefit (OB) }\end{array}$ & 2 & 1 & 0,750 \\
\hline Satisfaction (S) & 1,3 & 2,4 & 0,902 \\
\hline Use (U) & 1 & 3 & 0,572 \\
\hline
\end{tabular}

Unidimensional reliability: regression weights

\begin{tabular}{|c|c|c|c|c|c|c|}
\hline Construct & item & and & Construct & item & $\begin{array}{l}\text { Modification } \\
\text { Indices }\end{array}$ & $\begin{array}{l}\text { Reduced } \\
\text { Parameter } \\
\text { Change }\end{array}$ \\
\hline IB & 2 & <-> & Q & 2 & 4,42 & $-0,11$ \\
\hline U & 1 & $<->$ & $\mathrm{AO}$ & 2 & 5,13 & $-0,10$ \\
\hline U & 1 & <-> & Q & 2 & 4,43 & $-0,11$ \\
\hline Q & 2 & $<->$ & IB & 2 & 6,81 & $-0,08$ \\
\hline U & 1 & $<->$ & $\mathrm{OB}$ & 2 & 4,51 & $-0,13$ \\
\hline$S$ & 4 & $<->$ & A & 1 & 4,08 & $-0,05$ \\
\hline$S$ & 2 & $<->$ & U & 2 & 5,80 & 0,06 \\
\hline$S$ & 1 & $<->$ & $Q$ & 1 & 6,05 & $-0,05$ \\
\hline
\end{tabular}

\begin{tabular}{|c|c|c|c|c|c|c|}
\hline Construct & item & and & Construct & item & $\begin{array}{l}\text { Modification } \\
\text { Indices }\end{array}$ & $\begin{array}{l}\text { Reduced } \\
\text { Parameter } \\
\text { Change }\end{array}$ \\
\hline $\mathrm{AO}$ & 1 & $<->$ & \multicolumn{2}{|c|}{ S (latent variable) } & 5,04 & $-0,07$ \\
\hline IB & 3 & $\langle->$ & $\mathrm{AO}$ & 2 & 4,40 & 0,09 \\
\hline IB & 2 & $\langle->$ & OB & 1 & 4,01 & $-0,08$ \\
\hline$Q$ & 2 & $\langle->$ & \multicolumn{2}{|c|}{ OB (latent variable) } & 5,46 & 0,06 \\
\hline Q & 2 & $<->$ & $\mathrm{AO}$ & 1 & 6,71 & 0,10 \\
\hline Q & 2 & $<->$ & IB & 3 & 4,59 & 0,05 \\
\hline Q & 2 & $<->$ & IB & 2 & 15,13 & $-0,12$ \\
\hline$Q$ & 2 & <-> & IB & 1 & 5,06 & $-0,07$ \\
\hline U & 1 & $<->$ & \multicolumn{2}{|c|}{ OB (latent variable) } & 6,43 & $-0,12$ \\
\hline U & 1 & $<->$ & $\mathrm{OB}$ & 2 & 4,94 & $-0,11$ \\
\hline$S$ & 3 & $<->$ & \multicolumn{2}{|c|}{ IB (latent variable) } & 7,93 & 0,08 \\
\hline S & 3 & $<->$ & $Q$ & 1 & 4,38 & 0,09 \\
\hline S & 4 & $\langle->$ & $\mathrm{AO}$ & 1 & 7,57 & $-0,09$ \\
\hline S & 2 & $\langle->$ & U & 2 & 9,85 & 0,10 \\
\hline S & 1 & $<->$ & $Q$ & 1 & 7,24 & $-0,09$ \\
\hline
\end{tabular}

Unidimensional reliability: Standardized Residual Covariances

\begin{tabular}{|c|c|c|c|c|c|c|c|c|c|c|c|c|c|c|c|c|c|c|}
\hline \multirow[b]{4}{*}{ בै। } & & \multicolumn{2}{|c|}{$\begin{array}{l}\text { Organizational } \\
\text { Net Benefit (OB) }\end{array}$} & \multicolumn{4}{|c|}{ Awareness of Others $(A O)$} & \multicolumn{3}{|c|}{$\begin{array}{l}\text { Individual } \\
\text { Net Benefit (IB) }\end{array}$} & \multicolumn{2}{|c|}{ Quality (Q) } & \multicolumn{2}{|c|}{ Use (U) } & \multicolumn{4}{|c|}{ Satisfaction (S) } \\
\hline & item & 1 & 2 & 4 & \begin{tabular}{|l|l|}
3 \\
\end{tabular} & 2 & 1 & \begin{tabular}{l|l}
3 & \\
\end{tabular} & 2 & 1 & 2 & 1 & 2 & 1 & 3 & 4 & 2 & 1 \\
\hline & 1 & 0,00 & & & & & & & & & & & & & & & & \\
\hline & 2 & 0,00 & 0,00 & & & & & & & & & & & & & & & \\
\hline \multirow{4}{*}{ 운 } & 4 & 0,94 & $-0,16$ & 0,00 & & & & & & & & & & & & & & \\
\hline & 3 & 1,11 & 1,08 & 0,18 & 0,00 & & & & & & & & & & & & & \\
\hline & 2 & 1,56 & 1,21 & $-0,08$ & $-0,11$ & 0,00 & & & & & & & & & & & & \\
\hline & 1 & 1,29 & 0,41 & 0,02 & $-0,21$ & $-0,14$ & 0,00 & & & & & & & & & & & \\
\hline \multirow[b]{2}{*}{$\cong$} & 3 & 0,17 & $-0,01$ & 0,24 & 0,35 & 1,68 & 1,64 & 0,00 & & & & & & & & & & \\
\hline & 2 & $-0,60$ & $-0,09$ & 0,62 & 1,28 & 0,97 & 1,85 & $-0,17$ & 0,00 & & & & & & & & & \\
\hline
\end{tabular}




\begin{tabular}{|c|c|c|c|c|c|c|c|c|c|c|c|c|c|c|c|c|c|c|}
\hline & 1 & 0,10 & $-0,17$ & $-0,79$ & 0,27 & $-0,35$ & 0,44 & 0,00 & 0,53 & 0,00 & & & & & & & & \\
\hline & 2 & 0,60 & 0,95 & $-0,79$ & $-0,83$ & 0,46 & 0,91 & 0,37 & $-1,23$ & $-1,19$ & 0,00 & & & & & & & \\
\hline 0 & 1 & 0,13 & 1,29 & 0,09 & 0,56 & 0,68 & 0,97 & $-0,11$ & 0,71 & 0,23 & 0,52 & 0,00 & & & & & & \\
\hline & 2 & 0,08 & 0,04 & $-0,74$ & $-0,29$ & 0,04 & 0,54 & $-0,17$ & 0,59 & $-0,23$ & 0,34 & $-0,24$ & 0,00 & & & & & \\
\hline & 1 & $-0,90$ & $-1,55$ & 0,40 & 0,43 & $-0,07$ & 0,74 & $-0,11$ & 0,45 & $-0,59$ & $-0,53$ & $-0,75$ & 0,07 & 0,00 & & & & \\
\hline & 3 & 0,55 & 1,11 & 0,06 & $-0,39$ & 1,21 & 0,52 & 0,81 & 0,67 & 0,31 & $-0,29$ & 0,82 & $-0,20$ & $-0,42$ & 0,00 & & & \\
\hline & 4 & 0,59 & 0,59 & $-0,04$ & 0,04 & 0,84 & $-0,45$ & 0,01 & $-0,26$ & $-0,42$ & 0,02 & $-0,13$ & $-0,37$ & $-0,37$ & 0,23 & 0,00 & & \\
\hline & 2 & 0,34 & 0,42 & 0,21 & 0,70 & 1,06 & 0,87 & $-0,10$ & 0,36 & $-0,66$ & $-0,07$ & $-0,28$ & 1,20 & $-0,42$ & $-0,08$ & $-0,28$ & 0,00 & \\
\hline$\omega$ & 1 & $-0,12$ & 0,05 & $-0,33$ & $-0,62$ & 0,18 & $-0,14$ & $-0,24$ & $-0,34$ & $-0,79$ & 0,22 & $-0,88$ & 0,05 & $-0,06$ & $-0,19$ & 0,03 & 0,21 & 0,00 \\
\hline
\end{tabular}

Table 6 The reliability

Statistical conclusion validity: The overall fit of the model

\begin{tabular}{|l|l|l|l|l|}
\hline NPAR & CMIN & DF & P & CMIN/DF \\
\hline 42 & 174,121 & 111 &, 000 & 1,569 \\
\hline RMR & GFI & AGFI & PGFI & \\
\cline { 1 - 4 } 0,057 & 0,929 & 0,902 & 0,674 & \\
\hline NFI Delta1 & RFI rho1 & IFI Delta2 & TLI rho2 & CFI \\
\hline 0,943 & 0,930 & 0,978 & 0,973 & 0,978 \\
\hline
\end{tabular}

Table 7 The overall fit of the model

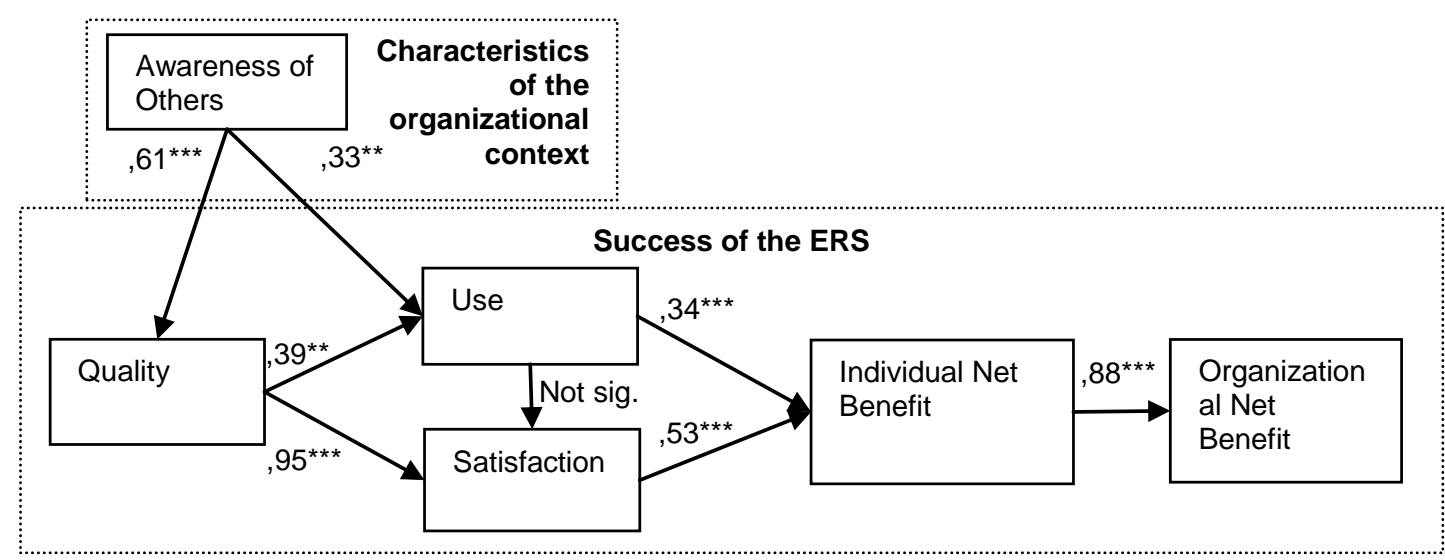

\section{Figure 4 The statistical conclusion validity of the model}

Standardized regression weights.

*** significant at 0,001\%;

** significant at 0,01\%;

not sig. not significant at 0,05\% 